\title{
O EXERCÍCIO DA CIDADANIA POLÍTICA EM PERSPECTIVA HISTÓRICA (PORTUGAL E BRASIL)*
}

\section{Manuel Villaverde Cabral}

\section{Introdução}

Esta pesquisa é uma continuação do trabalho que desenvolvo há vários anos sobre as relações entre cidadania política e eqüidade social em Portugal (Cabral, 1997). Ambas as categorias carecem, todavia, de operacionalizações mais consis-

* Este texto é uma nova versão muito modificada e aprofundada de dois artigos publicados anteriormente: "O exercício da cidadania política em Portugal”, em M. V. Cabral, J. Vala e J. Freire (orgs.), Trabalbo e Cidadania, Lisboa, ICS, 2000; "Autoritarismo de Estado, distância ao poder e familismo amoral: uma pesquisa em progresso", em A. Cohn, A. Camargo e B. S. Santos (orgs.), Brasil-Portugal entre o passado e o futuro: o diálogo dos 500 anos (Actas do Congresso Brasil-Portugal Ano 2000 - Secção de Sociologia \& Antropologia; Recife, 1999), Rio de Janeiro, EMC, 2001.

Conferência proferida durante o XXVI encontro Anual da ANPOCS, em Caxambu-MG tentes, que exigem, por seu turno, definições mais rigorosas de cada uma delas. Ora, enquanto a categoria da eqüidade social continua a se beneficiar da intensa exploração empírica que tem sido feita por sociólogos e politólogos (Kluegel et al., 1995; G. Marshall et al., 1997) a partir da obra seminal de John Rawls (1971), o mesmo já não se pode dizer da categoria da cidadania política, embora haja uma vasta literatura produzida sob a rubrica genérica da cidadania nas duas últimas décadas (Turner e Hamilton, 1994).

De uma forma geral, as operacionalizações politológicas do conceito de cidadania caracterizam-se por excessivo grau de "formalismo", isto é, tendem a subordinar a construção dos indicadores aos caracteres processuais do regime representativo, tais como os procedimentos eleitorais (Luhmann, 1980). Em contrapartida, outras concepções da cidadania privilegiam o respeito pelos direitos humanos e, em alternativa ou em combi- 
nação, pelos direitos sociais dos cidadãos (Saward, 1994; Poppovic e Pinheiro, 1995). Sem prejuízo do papel que esses últimos direitos desempenham numa concepção global da cidadania contemporânea, não me ocuparei deles aqui, pois o que me interessa, nesta fase da pesquisa, são as questões relativas ao exercício da cidadania política propriamente dita.

\section{A especificidade dos direitos políticos}

Com efeito, há uma diferença de natureza tanto entre os direitos civis como os direitos sociais, por um lado, e os direitos políticos, por outro. Habitualmente, essa diferença é obliterada na literatura, a qual tende, na linha do esquema clássico de $\mathrm{T}$. H. Marshall (1992), a tratar as "três gerações" de direitos como se eles se inscrevessem num simples contínuo. Embora numa perspectiva diversa, algo de semelhante sucede também com Rawls, ao conceber a evolução do binômio liberdade-igualdade em três etapas: a da liberdade natural, correspondente aos direitos civis de Marshall; a da igualdade liberal, correspondente aos direitos políticos formais; e a da igualdade democrática, correspondente à eqüidade social necessária, segundo Rawls, para conferir um valor substantivo à igualdade formal (Rawls, 1971, cap. 12, pp. 65-75).

Ora, independentemente da validade histórica do contínuo dos direitos de cidadania, aliás discutida na literatura (Turner, 1993), a cidadania política possui uma especificidade que não só justifica tratamento sociológico próprio, como também torna problemática a eventualidade de aquele contínuo ser alterado, conforme teria sucedido por exemplo no Brasil (Santos, 1998a; Carvalho, 2001). Com efeito, onde são reconhecidos, os direitos da igualdade civil, tal como Marshall os concebe, tendem a ser usufruídos de forma, por assim dizer, passiva, isto é, sem que para isso os seus beneficiários tenham de se mobilizar. O mesmo acontece com os direitos sociais subsumidos no moderno welfare state, cujos benefícios são em princípio gozados por todas as pessoas que reúnam as condições legais. ${ }^{1}$

Como é evidente, nenhum desses direitos foi obtido sem lutas sociais nem é usufruído, na prática, de forma idêntica por todos os membros de uma mesma sociedade. Contudo, nos Estados onde os direitos civis e sociais vigoram constitucionalmente, os cidadãos não podem exercê-los de forma activa e, caso sejam discriminados, têm o direito suplementar de recorrer às instâncias judiciais nacionais e, em alguns casos, até supranacionais encarregadas de velar pela sua aplicação. Já o mesmo não sucede com os direitos políticos propriamente ditos, ou seja, a liberdade de expressão e de associação, bem como o direito de eleger e ser eleito para todos os cargos representativos. ${ }^{2}$

Com efeito, os cidadãos podem usufruir desses direitos constitucionais sem os exercerem plenamente. Ao contrário dos direitos cívicos e sociais, os atributos da cidadania política nunca são automáticos, mas sim algo que tem de ser exercido individualmente de forma ativa. ${ }^{3}$ Como escreve Jon Elster, "as liberdades têm de ser exercidas e não só garantidas" (1993b, p. 98). Ora, como é sabido, em nenhuma sociedade a cidadania política é exercida de forma igual e plena por todos os seus membros. Na sociedade portuguesa também não. É pois desta desigualdade presente e passada que me ocuparei.

Quanto ao que se passa no Brasil, não entrarei, naturalmente, em pormenores. Limitar-meei a admitir que alguns dados apresentados por Murilo de Carvalho em texto recente, segundo os quais apenas $2 \%$ dos habitantes da área metropolitana do Rio de Janeiro teriam sido capazes de mencionar um dos seus direitos políticos, configuram também uma situação deficitária no que diz respeito ao exercício da cidadania (2002, p. 26). A situação já é diferente no que concerne à participação eleitoral, cujo aumento espectacular tem sido amplamente demonstrado por Wanderley Guilherme dos Santos (1998, pp. 115-192). ${ }^{4}$

Problema mais complexo é, sem dúvida, aquele que Santos levanta a propósito do que chamou de cidadania regulada (1998a, pp. 63114). Com efeito, no Brasil, como aliás em outros países, segmentos relevantes da população assalariada urbana acederam precocemente a um pacote significativo de direitos sociais, por assim dizer, em troca dos direitos políticos confiscados 
pelo regime de Vargas. Resta saber se essa política de bem-estar é, para usar as palavras do autor, "legítima, isto é, não considerada como paternalista" (Idem, p. 40) e se a "cidadania regulada" pode ser equiparada à cidadania política no sentido que tenho usado. Não creio que seja o caso, desde logo porque a "regulação" dessa "cidadania" se fez privando-a do exercício dos direitos políticos básicos.

Diverso e diretamente relacionado com a presente pesquisa, é o crescente recurso individual ou coletivo aos novos institutos processuais da "ação popular" e da "ação civil pública", criados pela Constituição brasileira de 1988 (Vianna, 2002), que não têm equivalentes em Portugal, embora parte desse tipo de ações se processe através da Provedoria de Justiça (Ombudsman), que constituiu certamente uma das mais importantes inovações jurídicas trazidas aos cidadãos pela democratização do sistema político português. Segundo os autores do estudo sobre "a democracia e os três poderes no Brasil", os cidadãos brasileiros, os seus advogados, os sindicatos, as ONGs e as "promotorias" têm-se mobilizado intensamente para tirar partido da "democratização do acesso ao judiciário" em defesa de seus direitos, tendendo "a moderar os efeitos negativos de uma representação política com pouca presença popular" e "admitindo oportunidades plurais para o exercício da cidadania" (Vianna e Burgos, 2002, p. 483).

\section{Por uma auditoria democrática}

Regressemos, porém, ao argumento principal. São raros os autores que levantam a questão da persistência de fortes traços oligárquicos de ordem societal nos sistemas representativos reais. Essa persistência pode, aliás, ser de dois tipos geralmente cumulativos: persistência genérica, como lamenta Rawls (1971, pp. 300 passim), ou específica, como denuncia Linz (1988, pp. 112113). Ora, em Portugal e não só, esses traços oligárquicos continuam a produzir fortes restrições sociais à assunção efetiva da cidadania política. Trata-se, pois, de restrições oligárquicas que se situam ainda no eixo da participação poliárquica, para não evocar o ideal-tipo da democracia, tal como definida por Wanderley Guilherme dos Santos na sua leitura crítica do conceito de Robert Dahl (1998b).

Carecemos, portanto, de operacionalizações do conceito de cidadania que, ao avaliarem o desempenho do processo democrático, não o subordinem ao ponto de vista da oferta de bens políticos, em detrimento do ponto de vista da procura desses bens por parte do cidadão individual ou associado. Em suma, são raras as propostas de escrutínio do exercício da cidadania que não subordinem a política como forum à política como mercado (Elster, 1985). O que pretendo fazer na primeira parte desta exposição é explorar empiricamente uma concepção da política democrática que não a subordine exclusivamente à oferta, sobre a qual paira sempre o condicionamento oligárquico, mas que também não faça dela um forum permanente, sem estrutura nem estabilidade, como Elster sugere, no artigo citado acima, ser o caso das teses de um autor como Habermas.

Um esforço nesta direção é o que fornecem, por exemplo, Beetham e seus colegas (1994), ao apelarem à realização de auditorias democráticas, isto é, confrontos empíricos entre os propósitos constitucionais da democracia e o seu desempenho efetivo, quer do lado da oferta partidária, quer do lado da procura de bens políticos, quer ainda do funcionamento das instituições para-políticas, como os tribunais e a mídia, para não falar neste momento nas instituições econômicas, pois isso levar-nos-ia de volta à questão da eqüidade social, que não pretendo analisar aqui. Como recorda Beetham, "do ponto de vista de uma avaliação crítica das democracias estabelecidas, os indicadores que tratam as práticas existentes como constituindo o auge das realizações democráticas parecem-nos indevidamente auto-congratulatórios". A observação é óbvia, mas nem por isso os cientistas sociais e políticos deixarão de tirar dela as devidas conseqüências.

Acresce que, com a chamada "terceira vaga" democrática e a correlativa deslegitimação de todos os regimes políticos não-representativos (Huntington, 1991), a alegada universalização da democracia fez deslocar os critérios formais de di- 
ferenciação entre regimes democráticos e não-democráticos para os critérios substantivos da qualidade da democracia (Schmitter, 1999). Em outras palavras, a diferenciação binária, por assim dizer absoluta, entre democracia e não-democracia tem cedido o passo, tanto do ponto de vista analítico como da vivência dos cidadãos, à diferenciação relativa entre sistemas representativos num contínuo de regimes de diferente qualidade.

Vou assim concentrar-me na medição do exercício efetivo dos direitos conferidos aos cidadãos em qualquer regime democrático consolidado, como é hoje o caso do regime português do ponto de vista constitucional. Por extensão da noção de cidadania, desenvolvi também um conjunto de indicadores destinados a medir a avaliação subjetiva que os cidadãos fazem do funcionamento do sistema político. Finalmente, recorri ainda ao indice de distância ao poder, concebido nos anos de 1960 (Hofstede, 1972), a fim de avaliar o posicionamento genérico da população portuguesa perante a forma como o poder político é, segundo ela, exercido. Em suma, trata-se de um inquérito extensivo ao desempenho do regime democrático português do ponto de vista das procuras manifestas e latentes de bens políticos compatíveis com a Constituição.

\section{Identificação partidária, posicionamento ideológico e participação eleitoral}

Abreviando a apresentação dos resultados do inquérito, o estudo confirmou a relativa debilidade da identificação expressa pelo eleitorado português em relação à oferta partidária disponível. Em 1997, fora de qualquer conjuntura eleitoral, $43 \%$ dos eleitores não manifestaram simpatia por qualquer partido e 3\% recusaram-se a responder; apenas $54 \%$ das respostas foram positivas. Em relação a 1994, a identificação partidária perdera seis pontos percentuais, sendo os dois maiores partidos que mais perderam (Cabral, 1997; 1999a).

Esse resultado não surpreende, sabendo que, em Portugal, quanto maior é o grupo dos "simpatizantes" de um partido, menor é a sua militância e menor é, também, a sua diferenciação mútua, bem como a sua diferenciação relativa ao perfil sociográfico do eleitorado. Dito de outro modo, os dois maiores partidos são, pelo simples fato de recolherem entre $70 \%$ e $80 \%$ do voto popular, os mais sujeitos à flutuação da opinião pública. Em termos internacionais, esses valores também já não são surpreendentes, ${ }^{5}$ confirmando o movimento de disengagement from democracy que vem afetando os eleitorados desde que a "terceira vaga democrática" se generalizou, tanto em regimes consolidados como emergentes (Johnston, 1993).

No que diz respeito ao posicionamento ideológico segundo a clássica escala de dez graus entre Esquerda e Direita, o resultado mais saliente é, porventura, o fato de $20 \%$ dos inquiridos não tomarem posição. Os restantes distribuem-se segundo uma curva normal, com forte concentração (37\%) nos dois graus centrais da escala $(5+6)$, mas com clara predominância do grau 5 (29\%). À Esquerda (graus 1-4) agrupam-se $24 \%$ e à Direita (graus 7-10), 17\%. As preferências do eleitorado português inclinavam-se, então, para a Esquerda do leque ideológico. Cruzando com a identificação partidária, é notório que, independentemente dos discursos e das práticas dos partidos, o eleitorado português possui um mapa razoavelmente claro das posições topológicas de cada um deles (ver Quadro 1, em Anexo).

Finalmente, apenas 21\% dos inquiridos admitiram não ter votado nas eleições anteriores à data do inquérito. Porém, considerando que as pessoas tendem a reconstruir o seu comportamento eleitoral de acordo com a espiral do silêncio, ou seja, submetendo-se verbalmente à norma social prevalecente (E. Noelle-Neumann, 1995), segundo a qual a abstenção eleitoral está sujeita a uma forte carga negativa, a débil identificação partidária dos cidadãos não deixou de se traduzir por abstenção significativa (Freire e Magalhães, 2002). Esses resultados revelam, portanto, uma insatisfação com a atual oferta político-partidária, ao mesmo tempo que confirmam o primado de facto da oferta sobre a procura no mercado eleitoral.

Embora o posicionamento ideológico dos cidadãos apresente correlações significativas e de 
sentido previsível com as principais variáveis sociais e atitudinais, só são expressivas as correlações positivas com a exposição à mídia informativa e a simpatia partidária. Quanto a esta última, a ausência de relações minimamente expressivas com os atributos sociais dos cidadãos significa que a desidentificação em relação à oferta político-partidária atravessa de forma quase indiferenciada o espectro da sociedade portuguesa. O mesmo sucede de maneira ainda mais acentuada, como veremos adiante, com a avaliação do sistema político e a distância ao poder.

\section{Participação associada e automobilização política}

Ao contrário da participação eleitoral, que constitui, de acordo com as teorias convencionais da democracia, um processo tendencialmente atomizado, a plena assunção da cidadania política passa pelo que chamei de participação associa$d a$. Esta corresponde a um processo ativo de resocialização vis-à-vis dos determinismos sociológicos habituais, bem como à aquisição de uma cultura cívica própria. Assim, numa teoria democrática que valorize a dinâmica interativa e resocializadora da participação, a propensão dos indivíduos para se associarem voluntariamente com vistas à promoção de valores e interesses comuns constitui não só o indicador mais aproximado para quantificar esse processo de participação explicitamente socializada e publicitada, como também uma medida do exercício efetivo dos direitos de cidadania política.

Ora, segundo o grau de envolvimento num conjunto de associações relevantes, ${ }^{6}$ verifica-se uma propensão para a participação associada muito baixa por parte do eleitorado português. Numa escala de cinco pontos, a procura manifes- ta de bens cívicos situa-se, em média, no ponto 4,5 (mediana e moda $=5$ ). A propensão para a ação coletiva sustentada fica, pois, muito aquém da procura latente de bens políticos expressa pela participação eleitoral, indicando, portanto, que esta última possui uma escassa ancoragem social. Com efeito, mais de dois-terços dos inquiridos revelaram um grau nulo de participação associada e outros $20 \%$, um grau baixo.

A propensão para a participação associada apresenta, como era de se esperar, correlações significativas e de sinal previsível com os atributos sociais da população, mas elas não são expressivas, exceto com o índice de mobilização política, de que falarei a seguir. Nesse sentido, a participação revela-se pouco sensível às determinações sociológicas, constituindo antes uma prática específica do processo de exercício dos direitos de cidadania, o qual dependerá de micro e mesofatores que uma macroanálise como esta não captou. Também não têm expressão as correlações com o posicionamento ideológico e as identificações partidárias, o que significa que a propensão para a ação coletiva das pessoas "de esquerda" é tão baixa quanto a das pessoas "de direita".

Um pouco mais expressivas são as correlações com a exposição à mídia informativa e a mobilização cognitiva (Cabral, 1997). Com efeito, esses últimos índices traduzem atributos reflexivos da mobilização política. Embora dependam do sistema de diferenciação social, sobretudo do nível de instrução e do lugar de classe, tanto a procura de informação como a disposição para intervir no espaço público e aí discutir temas de caráter político constituem, em si próprias, manifestações potenciadoras do exercício da cidadania. Em outras palavras, o espaço público continua a ser um lugar privilegiado da mobilização política, mas se é verdade que "nada politiza mais do

Tabela 1

Participação associada (\%)

\begin{tabular}{|c|c|c|c|c|c|}
\hline Muito alta & Alta & Média & Baixa & Nula & Média \\
\hline 1,3 & 4,5 & 6,0 & 20,3 & 67,9 & $\mathbf{4 , 5}$ \\
\hline
\end{tabular}


que a politização", ainda é preciso que os cidadãos entrem nesse espaço público para que a politização comece a ter lugar, e é isso que, freqüentemente, não ocorre.

Com efeito, o processo de socialização política está genericamente pré-condicionado pelo valor que os inquiridos atribuem à sua própria opinião. Assim, quem revela uma alta propensão para a ação coletiva coincide com quem considera a sua opinião importante; inversamente, quem revela propensão nula para se associar, considera que a sua opinião pouco ou nada conta. Ora, enquanto o primeiro grupo representa apenas 3,5\% do eleitorado português, o segundo corresponde praticamente a 40\%. Resta saber se há causalidade entre as duas atitudes e, caso haja, qual é o sentido dela. Será que aqueles que se organizam coletivamente ganham consciência de que a sua opinião conta ou será a percepção de que a sua opinião conta que leva uma minoria de pessoas a mobilizar-se? É o que tentamos ver a seguir.

A fim de conhecer a propensão dos cidadãos portugueses para se automobilizarem em defesa de interesses e valores próprios, individuais ou coletivos, sem aguardarem, por exemplo, a mobilização partidária com vistas ao voto, construímos um índice reunindo oito tipos de ação empreendidas ou susceptíveis de ser empreendidas pelos cidadãos. Ao contrário do que sucedia com a participação associada, a automobilização distribui o eleitorado português de forma bastante mais equilibrada, pois este novo índice inclui também indicadores de ordem atitudinal com menor significado em termos de práticas cívicas e políticas efetivas. No topo da mobilização política continua a encontrar-se uma escassa minoria de "hipermobilizados". Em contrapartida, só 24\% dos inquiridos se excluem, pelo menos pelas suas atitudes, de qualquer forma de mobilização. Em suma, numa escala de cinco pontos a média situa-se em 3,6.
Mais do que a identificação partidária, a posição ideológica ou a participação associada, a automobilização apresenta correlações significativas, de sinal previsível, com os principais caracteres sociográficos da população, notadamente o nível de instrução e a idade, sendo as pessoas mais instruídas e mais jovens as que revelam maior tendência para se mobilizarem. A automobilização está também correlacionada, embora mais mitigadamente, com a mobilização cognitiva e a exposição à mídia informativa, que assim continuam a andar a par. Em contrapartida, a classe social e o rendimento possuem fracas correlações, mostrando a mobilização depender mais diretamente do "capital escolar" do que do "capital econômico" ou do chamado habitus de classe.

Finalmente, verificou-se que não há relação necessária entre as ações que os cidadãos revelaram ter empreendido e aquelas que, embora nunca as tendo empreendido, admitem a possibilidade de vir a fazê-lo. Daqui se podem deduzir dois tipos de mobilização: as formas moderadas, que embora desigualmente postas em prática, são assumidas como legítimas por metade das pessoas, tais como assinar uma petição ou convocar uma reunião; e as formas radicais, também desigualmente postas em prática, mas que uma clara maioria recusa empreender, tais como fazer greve ou se manifestar na rua (ver Quadro 2, em Anexo).

\section{Para a construção de um índice de cidadania}

Se admitirmos, ao contrário de certas teorias conservadoras da democracia, que a qualidade de um regime democrático será tanto maior quanto mais os cidadãos exercerem os seus direitos, teremos uma noção melhor do funcionamento real do regime português, assim como se conseguirmos chegar a uma medida aceitável do exercício efetivo

Tabela 2

Índice de auto-mobilização política (\%)

\begin{tabular}{|c|c|c|c|c|c|}
\hline Muito forte & Forte & Média & Fraca & Nula & Média \\
\hline 5,2 & 11,1 & 30,2 & 29,1 & 24,4 & $\mathbf{3 , 6}$ \\
\hline
\end{tabular}


Tabela 3

Índice de cidadania política (\%)

\begin{tabular}{|c|c|c|c|c|c|c|c|c|c|c|}
\hline $\begin{array}{c}\mathbf{1} \\
\text { Muito } \\
\text { forte }\end{array}$ & $\mathbf{2}$ & $\mathbf{3}$ & $\mathbf{4}$ & $\mathbf{5}$ & $\mathbf{6}$ & $\mathbf{7}$ & $\mathbf{8}$ & $\mathbf{9}$ & $\begin{array}{c}\mathbf{1 0} \\
\text { Muito } \\
\text { fraco }\end{array}$ & Média \\
\hline- &, 06 & 1,5 & 1,6 & 4,2 & 8,4 & 14,8 & 23,1 & 24,8 & 21,1 & $\mathbf{8 , 1}$ \\
\hline
\end{tabular}

Tabela 4

Índice de avaliação do sistema político (\%)

\begin{tabular}{|c|c|c|c|c|c|}
\hline Muito positiva & Positiva & Média & Negativa & Muito negativa & Média \\
\hline 4,1 & 16,9 & 40,2 & 26,9 & 11,9 & $\mathbf{3 , 3}$ \\
\hline
\end{tabular}

da cidadania em Portugal, combinando os índices de participação associada e de automobilização.?

Verifica-se deste modo que perto de $70 \%$ dos cidadãos se situa nos três graus inferiores da escala. A média e a mediana situam-se no grau 8 e a moda no 9. A automobilização tem mais peso na formação do índice do que a participação associada, sendo, portanto, a baixa propensão dos inquiridos para a ação coletiva - em suma, aquilo a que Oliveira Vianna chamava o insolidarismo a principal responsável pelos baixos valores médios encontrados. Por sua vez, a instrução é o fator com mais peso no exercício da cidadania. Porém, como já foi observado em estudos ecológicos sobre o comportamento do eleitorado português (Freire, 2001), também no âmbito individual se verifica ser fraca a associação entre os atributos sociais da população, por um lado, e as suas práticas e atitudes político-ideológicas, por outro (ver Quadro 3, em Anexo). Na realidade, os únicos atributos sociais com incidência no exercício da cidadania são, além da instrução, a classe social e o gênero, sendo os homens mais instruídos das classes elevadas quem acaba por revelar maior propensão para exercer os seus direitos políticos. ${ }^{8}$ Et ceteris paribus, a mobilização cognitiva e a exposição à mídia, bem como o posicionamento ideológico à esquerda, funcionam como potenciadores do exercício da cidadania (ver Quadro 4, em Anexo).

\section{Avaliação do sistema político e distância ao poder}

Tem possivelmente razão Wanderley Guilherme dos Santos no seu "radical cepticismo quanto à possibilidade de completa avaliação da política cívico-social do governo" (Santos, 1998a, p. 63). Com efeito, os esforços que tenho feito para medir a avaliação que os cidadãos portugueses fazem de sistema político, na dupla dimensão do comportamento da classe política e da isenção dos aparelhos de Estado, não têm sido muito bem-sucedidos, pois as respostas revelam pouca consistência interna. Quando agregada, a avaliação limita-se a seguir uma curva normal com alguma propensão para o descontentamento, indicando que estamos perante dimensões das atitudes sociais em relação à oferta de bens políticos desligadas entre si.

Não surpreende, portanto, que a avaliação do sistema político não apresente associações significativas com qualquer variável sociográfica. Em contrapartida, está moderadamente correlacionada com o índice de distância ao poder, o qual, como veremos, também não apresenta correlações significativas com qualquer outro atributo ou atitude dos cidadãos. As dimensões com maior peso na avaliação do sistema político são a apreciação relativamente positiva do comportamento dos governantes e a apreciação relativamente negativa dos partidos. Essa 
Tabela 5

Índice de distância ao poder (\%)

\begin{tabular}{|c|c|c|c|c|c|c|}
\hline $\begin{array}{c}\mathbf{1} \\
\text { Mínima }\end{array}$ & $\mathbf{2}$ & $\mathbf{3}$ & $\mathbf{4}$ & $\mathbf{5}$ & $\begin{array}{c}\mathbf{6} \\
\text { Máxima }\end{array}$ & Média \\
\hline 4,2 & 14,0 & 23,1 & 29,4 & 24,7 & $4, .7$ & $\mathbf{3 , 7}$ \\
\hline
\end{tabular}

distinção entre o comportamento dos governantes e o dos partidos não surpreende, pois os cidadãos não só já haviam manifestado débil identificação com o sistema partidário, como é conhecida a tendência geral do público para dar mais apoio às autoridades do que ao próprio sistema. Em contrapartida, esta marcada disjunção entre a política partidária e a esfera do governo aponta diretamente para os resultados adiante fornecidos pelo índice de distância ao poder.

Como se podia antecipar, a avaliação do sistema é condicionada pelo relacionamento das pessoas com a política. Assim, 60\% revelam "ter dificuldade ou não compreender de todo o que se passa no mundo da política", ao mesmo tempo que $56 \%$ consideram que "a sua opinião pouco ou nada conta para resolver os problemas do país". É como se, para a maioria dos cidadãos, a compreensão da política e a importância de suas opiniões dependessem mais deles próprios do que da transparência do espaço público, por um lado, e da conta em que o sistema tem as suas opiniões, por outro. Como era também de prever, a compreensão e a influência políticas estão ligadas entre si, embora de forma menos linear do que se poderia supor. Resta saber se existe causalidade entre elas ou se, como já temos elementos para suspeitar, a percepção de compreender a vida política e a de ter influência sobre ela são pura e simplesmente indissociáveis, opondo uma minoria com acentuados traços oligárquicos a uma maioria distante do poder (ver Quadro 5, em Anexo).

Confirma-se, em todo o caso, que a compreensão e a influência políticas condicionam a participação e a mobilização dos cidadãos. Em suma, apesar de os cidadãos adoptarem atitudes perante o sistema político desligadas entre si e só debilmente relacionadas com os seus atributos sociais, foi possível identificar um conjunto de di- mensões do seu relacionamento com a política que indicia um distanciamento sensível em relação ao poder político. O índice de distância ao poder que usei foi adaptado daquele que o psicólogo social Geert Hofstede construiu, na segunda metade dos anos de 1960, a fim de medir a relação de autoridade entre os empregados e a direcção de uma grande empresa multinacional presente, na altura, em quarenta países entre os quais Portugal (Hofstede, 1972). ${ }^{9}$

Ora, verifica-se que a distância manifestada pelo conjunto da população portuguesa é superior à do segmento populacional inquirido há trinta anos. ${ }^{10}$ Isso significa que a esmagadora maioria dos portugueses considera que os governantes exercem o poder de forma diametralmente oposta à desejada pelos cidadãos, ou seja, tomam as decisões sem os consultar. Mais significativo quanto às suas determinações e consequências é, porém, o fato de uma idêntica maioria pensar que "os portugueses têm medo de mostrar que discordam das decisões dos governantes".

O resultado é que, numa escala de 6 graus, o distanciamento em relação ao poder político se situa, em média, no ponto 3,7. Quando procuramos os correlatos sociais, atitudinais e comportamentais dessa distribuição, o fato de ela se aproximar de uma curva normal, ao contrário do que sucedia com o índice de cidadania, confirma que a distância ao poder não apresenta correlações significativas com qualquer variável social, exceto uma débil associação, assinalada há pouco, com a avaliação do sistema político, sendo esta última tanto mais negativa quanto maior for o distanciamento. Em outras palavras, esse sentimento de distância ao poder atravessa indiferenciadamente a sociedade portuguesa.

É lícito pensar que esse traço societal marcante configura aquilo que se pode designar, na 
linguagem da política como forum, como um déficit comunicacional entre governantes e governados. No vocabulário da política como mercado, poderá dizer-se que esse mesmo traço societal configura um desajustamento entre a oferta e a procura no mercado dos bens políticos. De qualquer modo, ambos os casos recordam os conflitos latentes entre elites e massas nos antigos regimes liberais oligárquicos e clientelares, o que fornece um inesperado pano de fundo para os níveis relativamente débeis de exercício da cidadania política por parte da população portuguesa.

\section{A cidadania em perspectiva histórica}

A elucidação deste fenómeno sem correlatos sociológicos captáveis pelos instrumentos convencionais da ciência política remete para a história política do país, se não para a sua cultura cívica. Somos assim conduzidos ao horizonte histórico e fenomenológico do Estado português. Em suma, como explicar - um quarto de século depois de o regime autoritário ter sido derrubado e da alegada consolidação do regime representativo - esse sentimento de distância ao poder que os testes estatísticos convencionais se revelam incapazes de elucidar? Eis o que me proponho tratar na segunda parte desta exposição.

A hipótese mais plausível foi perguntar em que medida não subsistiria em Portugal, nas relações entre as elites de poder e a generalidade da população, um distanciamento histórico que a passagem do Estado autoritário ao Estado democrático não havia feito desaparecer. Daí, a evocação de um "autoritarismo de Estado" que não só subsistiria à democratização formal da representação e das instituições políticas, como seguramente precedera a institucionalização de um Estado autoritário demasiado duradouro, como o regime ditatorial de Salazar, para não carecer de explicação metapolítica e para não deixar marcas profundas para além da sua vigência contingente.

Vários autores estrangeiros exploraram, aliás, a possibilidade de existir, independentemente de juízos de valor sobre a ditadura, uma forte adequação do regime salazarista não só em nível de desenvolvimento socioeconômico, mas também no âmbito da cultura política da sociedade portuguesa da época, se não mesmo de sempre (Wiarda, 1977; Robinson, 1979; Schmitter, 1999). Bem antes deles, já no Brasil alguém como Oliveira Vianna argumentara com força no sentido da necessidade de um "estado corporativo forte" perante a inadequação das instituições políticas democráticas à sociedade brasileira. Por outro lado, mais de um autor brasileiro, entre os quais avulta sem dúvida Raymundo Faoro, tem imputado ao Estado colonial, se não à própria sociedade portuguesa, uma cultura autoritária - entre o patrimonialismo e a burocracia administrativa ou a uma combinação de ambos - legada ao Brasil. ${ }^{11}$ Habitualmente, porém, os autores portugueses identificados geracionalmente com a transição democrática, como eu próprio, tinham tendência para resistir a essas idéias. ${ }^{12}$

\section{A tese das sociedades civis reais}

Seja como for, o prolongado autoritarismo societal implícito na distância ao poder sentida pela maioria da população portuguesa no final do século XX possui, hoje em dia, um enquadramento teórico e metodológico novo, fornecido pela experiência da chamada terceira vaga democrática e pelas enormes dificuldades verificadas na emergência de "sociedades civis" que supostamente renasceriam após a derrocada dos Estados autoritários que as teriam subjugado até então. Com efeito, em vez de uma sociedade civil pujante e vibrante, correspondente aos ideais liberais, o que emergiu na maior parte dos países onde esses regimes imperavam foram as forças latentes naquilo a que Jeffrey Alexander deu, prosaicamente, o nome de "sociedades civis reais", sempre muito diversas do ideal-tipo liberal, tanto na sua composição social quanto no seu papel político. O fenômeno não é, aliás, exclusivo das democracias emergentes, tendo ressurgido em muitas democracias consolidadas à medida que o desmantelamento da intervenção e da regulação estatais avança perante a 
globalização neo-liberal (Alexander, 1998). A mais-valia trazida pela abordagem de Alexander e alguns dos seus colaboradores, relativamente à tradição dos "descontentes com a sociedade civil" (Cohen e Arato, 1992, pp. 275-341), reside na tentativa de conferir à tradição crítica normativa novas bases historiográficas, sociológicas e antropológicas.

Foi nesse novo quadro teórico e histórico que a colega brasileira Elisa Pereira Reis (Reis, 1998, maxime pp. 111-134) recuperou uma antiga noção dos estudos rurais que oferece, por assim dizer, uma base para fundamentar, de forma minimamente objetivada, o sentimento de distância ao poder que encontrei entre a população portuguesa de hoje. Trata-se da noção de familismo amoral, cunhada há mais de quarenta anos pelo sociólogo norte-americano Edward Banfield, a fim de caracterizar aquilo a que dava o nome, numa linguagem à qual também já não estamos habituados, as "bases morais de uma sociedade atrasada" (Banfield, 1958/1976). A referência revelou-se importante para esta estratégia de pesquisa, comparativa entre Portugal e Brasil. Com efeito, eu próprio já me havia deparado, na década de 1980, com algo de semelhante à estrutura e às funções desse familismo amoral, no meu próprio trabalho sobre as estratégias de adaptação e resistência do pequeno campesinato português perante a penetração de relações mercantis nos campos secundada pelos diversos aparelhos de Estado (Cabral, 1983, 1986, 1991).

De acordo com a tese das sociedades civis reais, o chamado familismo amoral fornece uma nova perspectiva sobre a "distância ao poder". E não só uma perspectiva passiva, exclusivamente associada à miséria econômica, como sucede predominantemente na reflexão de Elisa Reis e do próprio Banfield, mas também uma perspectiva de algum modo ativa. Em outras palavras, embora efetivamente perverso em muitos de seus efeitos para as próprias famílias, o familismo amoral ganha em ser dissociado da miséria pura e simples, ao mesmo tempo que convém reconhecer-lhe um carácter estratégico, como aliás sucedia também com o "insolidarismo" de Oliveira Vianna.

\section{Em busca de algumas mediações históricas}

Dando provisoriamente por definido o alegado familismo amoral das camadas sociais historicamente mais desmunidas da sociedade portuguesa, em especial o campesinato pobre do Norte e Centro do país, ${ }^{13}$ convém ter presente o grande peso quantitativo dessas camadas e o seu prolongado impacto nas representações e práticas sociais do conjunto da população, sobretudo as atitudes e os comportamentos políticos. Resta assim identificar alguns elos socioculturais susceptíveis de mediar entre tal familismo amoral e o autoritarismo do Estado português, aquém e além das formas contingentes que este tem tomado ao longo de um período que recua aos primórdios da modernidade em Portugal, com seus prováveis ecos no Brasil.

Voltemos atrás por um instante. Não sendo mais do que um construto quantitativo fabricado há trinta e tantos anos, o que a decomposição do índice de "distância ao poder" mostra é que há uma enorme distância entre as "formas democráticas" como a população considera que o poder político devia ser exercido e as "formas autoritárias" como ela acha que o poder é exercido de fato. Esse resultado é relativamente trivial e pode seguramente ser encontrado em muitas sociedades. Mas o exercício não mostrou apenas isso. Revelou também algo menos trivial. A saber: a grande maioria dos Portugueses teria, segundo os entrevistados, medo de mostrar discordância perante as decisões dos detentores do poder. ${ }^{14}$

Após um quarto de século de funcionamento regular das instituições representativas, com freqüentes alternâncias partidárias no poder, é inegável que estamos ante um indicador que remete, necessariamente, para algo mais do que a simples inércia do receio que a maioria dos portugueses tinha, por razões compreensíveis, de exprimir a sua opinião no tempo da ditadura. Tendo presente que mais de metade do atual eleitorado português chegou à maioridade (18 anos) depois das primeiras eleições livres em 1975, quando não nasceu já em democracia, é manifesto que a renovação demográfica das gerações foi insuficiente para trazer consigo uma renovação equivalente 
dessa atitude receosa, aliás não apresentando o indice de distância ao poder qualquer relação com a idade dos inquiridos.

É provável que, se este estudo tivesse sido feito durante o período de grande mobilização que se seguiu ao golpe do 25 de Abril de 1974, os resultados fossem diferentes. Nunca o saberemos, porém. Certo é que, com a desmobilização popular necessária, segundo as teorias convencionais da democracia, para a normalização do regime representativo; com a rotinização da participação eleitoral e da alternância partidária no governo; e finalmente, com a reoligarquização da classe política, os fatores de distância ao poder' de que o Estado autoritário já havia certamente se beneficiado, ao mesmo tempo que os reproduzira e consolidara, voltaram a produzir efeitos similares sobre as representações e as práticas políticas da maioria dos portugueses perante o Estado democrático. Dar conta dos fatores que têm sustentado a reprodução dessa cultura cívica marcada por uma indiferenciada "distância ao poder" e um débil exercício dos direitos de cidadania remete, pois, para um universo de mediações históricas com o qual a politologia empírica está menos habituada a lidar.

\section{A variável mais independente do sistema}

Precisamos, contudo, de uma ponta para puxar esse novelo de mediações a fim de identificar o que possa estar, por assim dizer, do outro lado da "distância ao poder" - por hipótese, o "familismo amoral" -, de maneira a que ela não surja como um vago traço cultural, mas sim como uma manifestação longamente consolidada das estratégias de sobrevivência de gerações sucessivas de famílias desmunidas não só de recursos econômicos, como sobretudo de recursos simbólicos, perante o exercício do mais simbólico dos poderes, a saber, o poder político.

Deste ponto de vista, a variável mais independente do sistema social português é, como tem sido repetidamente observado em todo o gênero de estudos, a posse desse tipo específico de recursos cognitivos e informativos que o sistema escolar é suposto fornecer desde a modernização do Estado, já a partir do século XVII e, decididamente, a partir do século XIX. Aliás, também nos Estados Unidos, como revela o último estudo de Sidney Verba e de sua equipe sobre "as raízes privadas da ação pública”, a educação continua a ser o único fator verdadeiramente significativo para a explicação de todos esses tipos de atitudes e comportamentos (Burns, Schlozman e Verba, 2001).

Em Portugal, para além da evidência contemporânea, há inúmeros indícios históricos de que a escolarização funcionou, ao longo dos processos de formação do Estado moderno, não só como um fator de apertado controle social, mas também como a forma mais regulada de acesso específico ao poder político. Entre tantos outros exemplos, é de mencionar a elegibilidade atribuí$\mathrm{da}$, no restrito sistema de franquia eleitoral liberal, aos detentores do $2 .^{\circ}$ grau de escolaridade secundária (os mesmos 9 anos da atual escolaridade obrigatória) sobre a grande maioria dos detentores de capital econômico, quando estes não possuíssem aquele modicum de capital cultural. É necessário verificar se essa disposição é comum a outros regimes eleitorais da época, mas é importante registar, desde já, a precedência política da instrução sobre o censo econômico desde os primórdios do Estado liberal em Portugal na primeira metade do século XIX. ${ }^{15}$

Com a institucionalização gradual do sistema de ensino formal, os dois capitais - econômico e cultural - tendem a convergir. Porém, enquanto se mantêm os dispositivos da escolarização restrita (Goody, 1986, 1987), como foi o caso em Portugal até à segunda metade do século XX, tal convergência de capitais não só reforça o caráter oligárquico das elites e a sua falta de diferenciação funcional, como aponta para a influência do "estamento burocrático", como lhe chama Faoro, na própria definição das regras do jogo político. Porventura mais ainda do que em nível nacional, é isso que se verifica na esfera das elites locais portuguesas com a implantação do sistema eleitoral liberal. ${ }^{16}$

A noção da alfabetização restrita remete, por seu turno, para algo que está por fazer em Portugal, pelo que aqui apenas lhe poderei acenar brevemente. Vale dizer que o que falta é uma espécie de história natural do analfabetis- 
mo e dos seus efeitos comunicacionais e políticos em Portugal. Porém, não se trata apenas da difusão da leitura e da escrita, mas também, a partir de certa altura, da difusão da imprensa. Terá sido neste momento crucial da difusão da palavra escrita através da imprensa e do seu impacto diferenciador nas "relações de comunicação", para usar a expressão de Jack Goody, que a Reforma e a Contra-Reforma introduziram na sociedade européia não só o cisma religioso, com o seu correlato na esfera de atitudes e comportamentos econômicos que estariam na base do "espírito do capitalismo", mas também um cisma equivalente, quiçá mais importante ainda do ponto de vista da gestão simbólica do poder, no sistema de comunicação entre elites e massas. Por definição, é mais fácil documentar o papel da comunicação escrita na emergência da "opinião pública", como mediadora entre Estado e sociedade civil (Zaret, 1998), nos países protestantes do que nos católicos, onde essa comunicação não existe ou é muito escassa.

Portanto, aqui apenas será possível assinalar essa escassez. Por exemplo, o controle absoluto da Coroa portuguesa sobre a difusão da tipografia na colônia, acompanhado da repressão violenta de quem se atrevesse a reproduzir qualquer texto sob forma gravada, é exemplar da centralidade política da imprensa no exercício do poder e, aliás, uma arma privilegiada na afirmação do estamento burocrático, bem como da centralização administrativa subjacente à unidade do império. A imprensa só chegou ao Brasil com a ida da corte para o Rio de Janeiro e ficou, inicialmente, sob o controle do poder colonial, com a criação da Imprensa Nacional em 1811, à imagem da congênere lusitana fundada em 1768.

\section{Para uma história do analfabetismo em Portugal}

O âmbito restrito deste artigo não comporta uma história do analfabetismo em Portugal. Porém, nada ilustrará melhor o cisma comunicacional entre elites e massas, aberto pela imprensa nos países católicos, do que a restrição sistemáti- ca à formação de camadas socioculturais intermédias - entre uma diminuta elite rapidamente alfabetizada e a grande massa iletrada dos camponeses pobres - com acesso aos textos sagrados. Com efeito, a proibição paradigmática que pendeu sobre a tradução e a impressão da Bíblia em vernáculo foi ainda mais prolongada em Portugal do que nos outros países católicos do Sul da Europa, já que a primeira bíblia impressa no país em língua portuguesa data apenas de finais do século XVIII. ${ }^{17}$

Bendix assinalou de forma definitiva a associação virtuosa entre a extensão da instrução pública e a cidadania política na construção do Estado moderno (Bendix, 1996, maxime cap. 3 da Parte II). Entre as conseqüências políticas - deliberadas ou não - da alfabetização restrita, que manteve o fosso entre os detentores do poder de regulação sobre a produção e a circulação da palavra impressa, por um lado, e as massas iletradas, por outro, Goody salienta o esmagamento de qualquer consolidação política do dissenso, impedindo, por assim dizer, que os conteúdos implícitos de potenciais dissensos se tornassem explícitos:

\footnotetext{
É claro que o cepticismo, a crítica e a descrença não estão ausentes das sociedades orais, mas a sua expressão tende a ser apagada a cada geração [...]. Não há acumulação de idéias não-conformistas. Os ataques contra a ordem política vigente tendem a assumir a forma de rebelião orientada ao restabelecimento da ordem anterior em vez da reforma, para não falar da revolução. Nas culturas alfabetizadas, os comentários individuais dos filósofos e pregadores adquirem uma forma permanente que a extensa circulação da palavra impressa pode cristalizar mais facilmente em ideologias conflituais [...]. Só a partir do momento em que a imprensa forneceu um modo regular de comunicação e exortação é que o dissenso se exprime como tal. Trata-se de mais uma ilustração das mudanças envolvidas no processo de tornar o implícito explícito (Goody, 1986, p. 122).
}

Tipicamente, no Brasil, entre as raras manifestações de rebeldia do "povo-massa", já Oliveira Vianna havia assinalado o carácter de "regresso à velha ordem" dos movimentos populares religiosos, como Canudos (Vianna, 1949); e Murilo de Carvalho diz algo parecido a propósito da 
"revolta da vacina" e da plebe urbana vista como "bestializada" pela elite liberal (J. M. Carvalho, 1987). Quanto a Portugal, não é necessário recordar a história da censura intelectual e dos seus efeitos compressores sobre o pensamento, para usar os termos de um clássico republicano (Bastos, 1926), nem o papel específico da Inquisição e das próprias autoridades políticas no apertado controle da alfabetização e da circulação da palavra impressa, a começar pelos textos sagrados do catolicismo em língua portuguesa. ${ }^{18}$

Em compensação, para fazer a história natural do analfabetismo, há necessidade de estudos históricos sobre a alfabetização e a respectiva quantificação. Esses estudos são ainda escassos em Portugal, mas, tanto quanto me é dado julgar, de boa qualidade e altamente informativos (Silva, 1986; Magalhães, 1994; Marquilhas, 1996). A quantificação do índice de alfabetização ao longo da história levanta, aliás, problemas metodológicos amplamente discutidos na literatura - em especial, a questão da inferência da extensão da alfabetização a partir das assinaturas em documentos de índole administrativa -, mas nem por isso resolvidos de forma satisfatória para uma abordagem dos seus efeitos comunicacionais e políticos. ${ }^{19}$ Seja como for, é importante notar que, a partir do século XVIII e, sobretudo, do século XIX, a alfabetização se tornou, em Portugal também, quase exclusivamente dependente de uma escolarização formal a cargo do Estado ou por este regulada. Paradoxalmente, a estatização do ensino contribuiu não só para fazer desaparecer as práticas informais de alfabetização, especialmente em meios sociais como o dos artesãos, mas também para desencadear um novo conflito latente entre o Estado e "populações que, não sentindo necessidade de se alfabetizarem, [encaram] a escola como uma violência inútil" (Magalhães, 1994, p. 519; ver também Ramos, 1988).

Outro sintoma do cisma entre as elites alfabetizadas e as massas iletradas é esse novo "factor de tensão entre estratos culturais devido ao preconceito dos analfabetos em relação aos que tresliam" (Marquilhas, 1996, p. 192). Esse preconceito, além de traduzir um mecanismo psicosocial de redução da dissonância cognitiva idêntico aos analisados por Jon Elster (1993a), constitui um traço típico de regimes comunicacionais como o dessa alfabetização restrita que prevaleceu em Portugal até à segunda metade do século XX, ou seja, até ao momento em que a maioria da população permanecia excluída do sistema de escolarização e a minoria que o freqüentava estava longe de atingir os critérios de elegibilidade de um século atrás. A própria fixação tardia da ortografia portuguesa faz também parte do carácter restrito da alfabetização. ${ }^{20} \mathrm{~A}$ arbitrariedade ortográfica e mesmo gramatical funciona, portanto, como um marcador direto do lugar na hierarquia sociocultural e também como um filtro suplementar no acesso à plena comunicação escrita. Em suma, trata-se de mais uma manifestação da instrução como forma de controle social.

Para concluir este esboço, bastará mencionar o estudo decisivo de Jaime Reis sobre o analfabetismo no século XIX, quando não havia no país, oficialmente, mais de $20 \%$ a $25 \%$ de pessoas alfabetizadas. Aí procede o autor à metódica refutação de todos os argumentos de índole econômica habitualmente invocados, em especial a falta de recursos do Estado, para explicar o enorme atraso da alfabetização das massas em Portugal, mesmo em comparação com os outros países católicos do Sul da Europa (Reis, 1993). Assim, definitivamente desarmados esses argumentos, fica como explicação para os elevadíssimos índices de analfabetismo e de analfabetismo funcional verificados em Portugal não só no século XIX, mas ainda no final do século XX (Benavente et al., 1996) - a manifesta falta de vontade das elites políticas em alfabetizarem as massas, só em parte justificada pelo fato de que não haveria, entre nós, necessidade de promover a uniformização lingüística. ${ }^{21}$ Contudo, as explicações fornecidas por Jaime Reis, atribuindo a falta de empenho das elites na alfabetização de massas à ausência de "maiores tensões" étnicas, sociais, políticas ou militares no país (Reis, 1993, pp. 3135 , maxime parágrafo final), iludem o papel crucial que o analfabetismo generalizado seguramente desempenhou, ao longo do século XIX e mesmo mais tarde, na relativa apatia política das classes populares (Cabral, 2001). 
Acoplada àquela falta de vontade política e legitimando-a de algum modo, terá funcionado, até há pouco tempo, uma simétrica falta de motivação das massas camponesas para a aprendizagem escolar, a qual remete, por seu turno, para a virtual irrelevância da comunicação escrita no quadro das estratégias econômicas e sociais - nomeadamente dos grupos domésticos do campesinato pobre que fornecem a base material do familismo amoral. Dito isto, não obstante os efeitos fortemente discriminantes que os níveis de instrução exercem sobre a maior parte das representações, atitudes e comportamentos da população portuguesa atual, isso mal se verifica para a "distância ao poder"; estatisticamente, apenas há uma relação inversa entre instrução e distanciamento perante o poder. Daí só se pode concluir que a chamada massificação do ensino verificada nas últimas décadas não exerceu sobre o sentimento de "distância ao poder" os efeitos que dela é costume esperar.

\section{O autoritarismo administrativo e sua ideologia}

Outra importante mediação a explorar entre o sentimento de distância ao poder e o quadro sociocognitivo configurado pelo familismo amoral é o carácter administrativo, magistralmente caracterizado por Raymundo Faoro em Os Donos do Poder, da dominação política exercida pelo Estado em Portugal e no Brasil ao longo da história. Mais do que qualquer outro instrumento ao seu dispor, inclusive a violência física, o autoritarismo recorrente do Estado português dá-se a conhecer pela administração pública. É através dela que as massas são, simultaneamente, integradas e discriminadas; às vezes, reduzidas a uma condição "bestializada". Em outras palavras, seria errôneo ver as massas camponesas do passado remoto e recente como camadas excluídas do Estado-nação. O que ocorreu é que o seu processo de inclusão - basicamente através da submissão aos procedimentos administrativos estatais - foi também o instrumento de sua discriminação.

Vale a pena, pois, equacionar a noção de Estado administrativo como forma de dominação preventivamente esvaziada de qualquer contratualização, como aquele despotismo administrativo que Tocqueville atribuiu ao Estado francês, antes e depois da Revolução (Tocqueville, 1856/1967). Trata-se de uma modalidade de subordinação das massas populares à parafernália das normas e de registos administrativos, em especial sobre a pequena propriedade camponesa e o sistema de herança, ao mesmo tempo que a maioria esmagadora da população era excluída, em Portugal, do acesso ao próprio instrumento de sua subordinação, a escrita. Esse tipo de dominação ter-se-á tornado ainda mais evidente com a liberalização formal das instituições políticas, notadamente nas sociedades da Europa meridional sob a influência da Revolução Francesa e do Império napoleônico.

Pensando na Itália de finais do século XVIII e inícios do século XIX, Adrian Lyttelton sublinha o fato de "a destruição da 'sociedade de ordens' não ter sido, inicialmente, realizada por fortes movimentos autóctones, mas ter-se apoiado quase exclusivamente na força da administração estatal", concluindo na esteira de Tocqueville, que "isto favoreceu a persistência de um modelo absolutista nas relações entre o cidadão e a administração" (Lyttelton, 2000, p. 66). Não é impossível que o Estado liberal português, e porventura o brasileiro também, se tenham encontrado perante o dilema do "comando impossível", como lhe chama o historiador Raffaele Romanelli, em que se encontrou o Estado italiano, ou seja,

[...] uma nova versão do dilema de forçar os homens a serem livres: o Estado liberal tinha de intervir para criar condições para o exercício da liberdade; porém, ao fazer isso, restringia a esfera de autonomia da sociedade civil, que a classe governante, sendo liberal, deveria proteger (Lyttelton, 2000, p. 67).

Seja como for, a articulação entre despotismo administrativo e analfabetismo é evidente. Rita Marquilhas, por exemplo, alude aos "efeitos mágico-simbólicos do escrito", sobretudo o impresso, mobilizados pelas autoridades políticas, desde o século XVIII pelo menos, na sua comunicação com as classes subordinadas (Marquilhas, 
1996, p. 192). Mas talvez nenhum estudo ilustre melhor o uso do analfabetismo como forma de controle e discriminação sociais do que o ensaio de Elisa Reis sobre a "opressão burocrática" no Brasil contemporâneo (1999, pp. 239-269), onde a autora analisa a correspondência enviada por incitação do ministro brasileiro Hélio Beltrão, quando do lançamento do seu Programa Nacional de Desburocratização em 1979.

Aí são citados numerosos cidadãos anônimos solicitando expressamente que a administração use "o português escrito da maneira que se fala". Segundo a autora, "quatro aspectos emergem claramente como noções bastante genéricas entre os correspondentes: a) o mito da "boa" autoridade; b) a burocracia como "mal" absoluto; c) o carisma da autoridade versus regras burocráticas; d) os 'direitos' como 'favores'” (Reis, 1999, p. 250). Esses traços identificam de forma exemplar as representações negativas que as massas iletradas tendem a ter da burocracia, acopladas a uma forte tentação carismática que acaba por legitimar, na realidade, o reverso do despotismo administrativo, ou seja, a dominação exercida por meio do carisma popular. Como aconteceu com o "modelo francês": do jacobinismo ao bonapartismo e, finalmente, ao Império.

Aplicados a Portugal, esses traços simultâneos de negatividade e positividade ajudam a entender o processo de consolidação da ideologia administrativa que domina o pensamento político português desde finais do século XVIII, atravessando virtualmente o reformismo iluminista, o liberalismo e o republicanismo. No Brasil, segundo Renato Lessa, uma ideologia administrativa análoga à portuguesa teria tido um momento de apogeu na consolidação da Primeira República sob a presidência de Campos Sales (Sales, 1998; Lessa, 1999). De resto, essa concepção administrativa do exercício do poder vinha já sendo teorizada, se não praticada, desde o Segundo Reinado, pelo Visconde do Uruguai, no seu Ensaio sobre o direito administrativo (1862), onde o autor recupera a lição conservadora de Guizot para ser, por sua vez, recuperado numa perspectiva autoritária por Oliveira Vianna, por exemplo (J. M. Carvalho, 2002b).
Em Portugal, o auge dessa ideologia teve lugar, tipicamente, com a ditadura do Estado Novo Corporativo a partir da década de 1930. Com efeito, o regime salazarista singulariza-se, em contraste com a breve ditadura carismática de Sidónio Pais que o antecedeu (1917-1918), por ter codificado rigidamente as tendências latentes do Estado liberal em direção ao que um autor da época chamara de "ditadura administrativa". Muito antes, também Oliveira Martins já usara a mesma expressão, em Portugal contemporâneo (1880), para caracterizar o governo de Costa Cabral, em finais da primeira metade do século XIX, por contraste com a agitação política - inorgânica, segundo Martins - dos primeiros tempos do Estado liberal. No início do século XX, um dos mais articulados ideólogos da República proclamada em 1910, Basílio Teles, abundara no mesmo sentido, não hesitando em teorizar o exercício da "ditadura administrativa" como forma rotineira de governar o país (As ditaduras, 1907).

De fato, o exame do pensamento político português moderno revela que raramente as elites se interrogaram acerca dos objetivos do poder ou em nome de quem exerciam esse poder. Todo o seu esforço doutrinário está dirigido a uma única questão: como exercer um poder do qual essas elites parecem considerar-se "donas", para usar a expressão de Raymundo Faoro? Subjacente à ideologia administrativa das elites oligárquicas, está, pois, o temor à irrupção das massas na cena política e, simultaneamente, à emergência de eventuais lideranças carismáticas, sobretudo à convergência dos dois fenômenos, segundo um padrão semelhante ao observado por Lyttelton na Itália, com o resultado de "consolidar a desconfiança no Estado" e colocar "problemas fatais para ao Estado liberal", desembocando no fascismo após a Primeira Grande Guerra (Lyttelton, 2000, p. 68).

\section{Práticas do despotismo administrativo}

A forma estatal do despotismo administrativo ajuda, por sua vez, a perceber dois fenômenos: o fechamento da estamento burocrático, no 
seio do qual se dilui a própria elite política e no qual são absorvidas, igualmente, as elites clerical e militar (Almeida, 1995); e a consolidação daquilo a que Joaquín Costa chamou há cem anos, pensando na Espanha, de "oligarquia e caciquismo". Com efeito, a ausência de relações políticas horizontais que caracteriza o familismo amoral próprio de largas camadas das classes subordinadas aponta, necessariamente, para a procura, em especial por parte das famílias camponesas, de relações verticais de intermediação e proteção para todos os aspectos que ultrapassam o domínio exclusivo do grupo doméstico e da economia familiar - desde o imposto, o voto e o serviço militar, até a obtenção de empregos assalariados, passando por todas as ocasiões da vida em que não é possível evitar o contato com a administração.

Tais relações verticais configuram, pois, o clientelismo como recurso assimétrico procurado por essas famílias junto dos "donos do poder" local e/ou nacional, trocando por exemplo voto por proteção pessoal, o que ajuda a explicar, por seu turno, a volatilidade de certos eleitorados em muitas democracias aparentemente consolidadas, como Banfield observou no sul da Itália em finais da década de 1950, sempre que há alternância no poder entre segmentos da oligarquia (Banfield 1976, pp. 48-56). Em Portugal, há tantos exemplos quantos se quiser para documentar esse tipo de pseudo-volatilidade eleitoral desde a implantação do liberalismo até hoje. Um dos primeiros a documentá-lo foi Léon Poinsard (1910), sociólogo da escola de Le Play que tanto influenciou Oliveira Vianna, chamado a Portugal pelos conselheiros do último rei, Manuel II, pouco tempo antes da proclamação da República.

Tudo isso nos leva a revisitar esse "familismo" e a sua pretensa "amoralidade". No meu entendimento, esta última nada mais é, de resto, do que a expressão prática da necessidade em que se encontram os grupos domésticos mais desmunidos de recursos materiais, sociais e cognitivos de apelar a todos os meios ao seu alcance - lícitos ou menos lícitos perante a moralidade demo-liberal contemporânea - a fim de se adaptarem e resistirem, como unidades de produção e reprodução que se vêem livres e autónomas (Cabral, 1998,
1995), a um meio hostil cuja face mais repressiva é, precisamente, o despotismo administrativo.

A própria "desconfiança" atribuída a essas camadas sociais - e, de fato, captada por todos os inquéritos de opinião feitos no Portugal de hoje tem a sua contraparte no Estado, que é o primeiro a "desconfiar" delas, como ocorre no exemplo caricatural, comum a Portugal e ao Brasil, da "prova de vida" que os cidadãos são freqüentemente obrigados a fazer, a fim de se beneficiarem de direitos que lhes são fornecidos como "favores" (Reis, 1998, p. 247). A idéia que sustento é que o formalismo, a rigidez e a própria morosidade dos procedimentos administrativos não são, como os discursos oficiais querem fazer crer, meras ineficiências susceptíveis de desejáveis correções; pelo contrário, do ponto de vista político, são instrumentos funcionais, se não deliberados, de poder, do poder.

Referindo-se ao Brasil de meados do século XIX, Maria Sylvia de Carvalho Franco caracteriza as relações entre autoridade oficial e influência pessoal no município paulista de Guaratinguetá de modo que poderia ser extrapolado tal qual para o Portugal da época e até muito mais tarde. Segundo ela, a diferenciação entre função oficial e vida privada "permitiu a extensão do poder oriundo do cargo público para a dominação com fins estritamente particulares [...] com toda a sorte de favoritismos à parentela e às amizades", transformando "a autoridade inerente ao cargo usada directamente em proveito próprio" (Franco, 1969, p. 133). Correlativamente, a "incapacidade para identificar interesses comuns e organizar-se institucionalmente em sua defesa" é também registada pela autora entre as camadas sociais intermédias do município, acrescentando que elas viam os seus "negócios públicos e privados através de um prisma ao mesmo tempo de solidão e dependência" (Franco, 1969, p. 148).

Com efeito, no que diz respeito às relações com o despotismo administrativo do Estado, a constelação de atitudes e comportamentos que venho designando por familismo amoral não só não se restringe às camadas mais desmunidas, como possui uma homologia com equivalente insolidarismo das elites, como aquele que Oliveira 
Vianna atribuiu tanto aos donos quanto aos agregados dos latifúndios. Obviamente, a abissal diferença de recursos entre os primeiros e os segundos faz com que modos equivalentes de lidar com a potência estatal determinem resultados que nada têm de semelhante, aqui terminando a sua equivalência funcional.

Em contrapartida, as comparações que tenho feito entre Brasil e Portugal, por superficiais que sejam, levam-me a insistir no fato de que, ao contrário do que acreditava Oliveira Vianna e muitos outros autores brasileiros, o insolidarismo entre pares e em relação ao exterior não tem ligação necessária com a propriedade latifundiária, já que na Europa meridional ele seria tipicamente um atributo do minifúndio. Em outras palavras, o fenômeno - insolidarismo ou familismo, como se lhe queira chamar - deve ser entendido, sobretudo, como uma forma de relacionamento entre as famílias e, sobretudo, entre elas e o exterior, em especial o Estado.

Em todo o caso, o círculo do despotismo burocrático e do familismo amoral fecha-se sobre si próprio, numa prática inexorável, quando as oligarquias partidárias preenchem os quadros da administração pública com seus clientes, muitas vezes filhos ou netos de camponeses pobres, entretanto alfabetizados e em busca de emprego seguro. Nada é mais fácil de documentar ao longo da história da construção do Estado contemporâneo em Portugal. ${ }^{22} \mathrm{O}$ clientelismo une, pois, o despotismo administrativo e o familismo amoral numa só relação reproduzida pelos partidos políticos modernos (Lopes e Freire, 2002).

\section{Como entender o familismo amoral?}

A concluir, pretendo resumir em quatro pontos aquilo que convém entender por familismo amoral, a fim de evitar as conotações pejorativas que a expressão pode hoje revestir, ao ser isolada do debate provocado, em especial na Itália, quando do aparecimento do livro de Banfield há aproximadamente quarenta anos. De resto, o debate não teve lugar apenas na Itália e prosseguiu durante bastante tempo depois da publicação do livro de Banfield, o que mostra a sua relevância para além das circunstâncias conceituais e temporais. ${ }^{23}$

Em primeiro lugar, o familismo amoral é aqui recuperado tão-somente como forma de identificar, no contexto de grupos domésticos rurais de escassos recursos socioculturais e economia quasiautárcica orientada à maximização do rendimento familiar indiviso (A. V. Chayanov, 1966), esse conjunto de representações e práticas que favorece, no seu relacionamento externo, notadamente com o Estado e o mercado do trabalho, o estabelecimento de relações verticais assimétricas (dependência clientelar) em detrimento de relações horizontais organizadas e estáveis, como são a participação cívica, o associativismo e a mobilização coletiva, em suma, os dispositivos convencionais do exercício dos direitos de cidadania política.

Para dar apenas um exemplo, se é certo que, como escreve Elisa Reis a propósito das cartas enviadas pelos cidadãos brasileiros ao Programa de Desburocratização, "a correspondência é em si mesma uma atividade política" (Reis, 1999, p. 258), que projeta o correspondente num universo de relações públicas formalizadas, então é lícito tomar a baixíssima propensão dos portugueses para escrever esse tipo de cartas, ${ }^{24}$ não só como um sintoma do insuficiente manejo da palavra escrita e do receio de deixar registo do seu dissenso, como também da posição de "distância ao poder" em que se encontra, perante o despotismo administrativo, grande parte de uma população socializada no âmbito do familismo amoral.

Em segundo lugar, o familismo não designa aqui nem um arcaísmo nem, muito menos, uma patologia psicosocial. De resto, o próprio Banfield teve o cuidado de demarcar essas idéias então muito propagadas - estávamos na Itália meridional dos anos de 1950 - até entre grandes meridionalistas italianos como Carlo Levi, autor do célebre Cristo si è fermato a Eboli (1947). Na realidade, Banfield adota, numa linguagem diversa da que usaríamos hoje, uma abordagem vizinha da "escolha racional", antecipando notadamente a teoria da ação coletiva, como assinala Chazel (1986). Escreve Banfield: 
A teoria segundo a qual um fatalismo desconsolado impediria o meridional de agir não explica, obviamente, as escolhas que ele faz quando de fato age. Nem explica, tampouco, por que razão, quando uma ação individual se apresenta como necessária, nem o desespero nem o fatalismo o impedem de levar a cabo [...]. Parece-nos possível afirmar que o pessimismo do meridional emerge quando se trata de iniciativas de base coletiva, mas não de ações individuais (Banfield, 1976, pp. 57 passim, maxime p. 63).

No decurso da acesa discussão que o livro desencadeou na Itália, Banfield recebeu inúmeros comentários, entre os quais se destacam os de Alessandro Pizzorno. Embora recusando a tentação de Banfield para colocar o ethos familista como a "variável independente" de todo aquele sistema social, a contribuição de Pizzorno tem a vantagem não só de reconhecer a realidade do fenômeno da escassa propensão daqueles camponeses pobres para ação coletiva, como sobretudo de o articular com o papel do despotismo administrativo como forma de dominação política inerentemente dissuasora das modalidades demo-liberais de mobilização cívica e política (Pizzorno, 1976, pp. 240-241). Por seu turno, a apatia política do campesinato português do Norte e Centro do país - desde a revolta da Maria da Fonte (1846) até ao Verão Quente de 1975, quando se revoltou contra o novo poder instituído em Lisboa - é reconhecida por todos os autores, sem prejuízo de fortes protestos ocasionais como os registados, durante a Segunda Guerra Mundial, contra a falta de subsistências e a carestia da vida (Cabral, 1999a).

Em terceiro lugar, o familismo amoral está longe de ser, no entendimento aqui feito, uma pura negatividade. Conforme o próprio Banfield reconhece, bem como Pizzorno, o alegado "amoralismo" do grupo doméstico acaba, de algum modo, por funcionar como um recurso estratégi$\mathrm{co}$, de que o clientelismo faz parte integrante não só no plano da proteção pessoal e familiar, como também no plano das relações com o sistema político. É excelente, aliás, a análise que Banfield faz das negociações entre os membros dos grupos domésticos, como eleitores, e a oferta partidária nos níveis local e nacional. Não deixa de ser significativo, também, que Pizzorno inclua o cliente- lismo - e a própria Máfia! - entre as formas de "solidariedade intermédia" ao dispor do grupo doméstico perante "a ordem imposta pelo Estado e a Igreja" (Pizzorno, 1976, p. 248). O mesmo se poderia dizer, mutatis mutandis, dos "clãs parentais e eleitorais" no Brasil, segundo Oliveira Vianna, e, mais perto de nós, segundo uma análise dos anos de 1960 sobre os "coronéis". ${ }^{25}$

O caráter positivo que o familismo adquire na manipulação personalizada da proteção clientelar e do próprio sistema político-partidário, por mais distorcidos que sejam muitos dos seus efeitos agregados, é mais evidente ainda no plano econômico, de acordo, aliás, com a teoria da economia camponesa de Tchayanov e Tepicht, quando se trata de explorações agrícolas familiares cuja orientação autárcica se explica pelo fato de a própria economia regional e/ou nacional estar muito pouco inserida nos mercados mundiais. Dito isto, Banfield não deixou de notar que o controle da natalidade e o investimento na escolarização dos filhos surgiam já, tipicamente, como a principal estratégia econômica - racional mas individual, no sentido não-liberal da família como indivíduo - com vistas ao "avanço na sociedade" (Banfield, 1976, p. 63). Todos esses traços estão abundantemente presentes nos estudos socioeconômicos sobre o campesinato pobre do Norte e Centro de Portugal, desde o clássico de Basílio Telles, A carestia da vida nos campos, no início do século XX.

Em quarto e último lugar, o familismo amoral não deverá ser concebido, como tende a acontecer tanto com Banfield quanto na utilização que Elisa Reis fez desta noção, como pertencendo exclusivamente à ordem da escassez absoluta de recursos econômicos, mas também à da privação relativa de recursos simbólicos, muito em especial a privação dos códigos de leitura e escrita que dão acesso aos arcanos do poder perante as formas sucessivas do despotismo administrativo do Estado. Com efeito, o familismo não é incompatível com estratégias bem-sucedidas de melhoria individual das condições econômicas dos grupos domésticos rurais (ou de origem rural, sendo aliás a emigração um dos recursos mais utilizados nessas estratégias). 
Desde o meu primeiro inquérito sobre as atitudes da população portuguesa ante o crescimento econômico, em 1991, aquilo que saltou à vista não foi tanto a privação econômica, nem o sentimento de falta de recompensas materiais para os esforços individuais de melhoria, mas, sobretudo, a profunda estratificação dos recursos simbólicos, desde a instrução à ação coletiva até a influência política. Os recursos distribuídos de forma mais desigual na sociedade portuguesa contemporânea não são os bens econômicos, mas sim o poder social e político (Cabral, 1997, pp. 43-78).

Assim, pode-se concluir que o incremento da eqüidade das oportunidades e recompensas econômicas não se traduz, automaticamente, num acesso mais equitativo ao poder simbólico, continuando muitos dos efeitos políticos do chamado familismo amoral a fazerem-se sentir para além das condições de escassez material que estiveram na sua origem. Inversamente, o sistema políticopartidário pode conhecer, como aconteceu em Portugal a partir de 1974, uma liberalização genuína, sem que as elites sociais tenham perdido o virtual monopólio da representação, o que era de algum modo previsível, mas nem sequer tenham perdido o controle da participação e da ação coletiva, preservando assim a sua forma histórica de dominação autoritária e excludente.

\section{Conclusão}

Não pretendo de forma alguma ter esgotado, neste ensaio exploratório, a problemática para que remete o sentimento de "distância ao poder" de que a maioria da atual população portuguesa está indiferenciadamente possuída. Porém, parece lícito ver nesse distanciamento o resultado de uma cadeia de efeitos compostos, cuja matriz pode ser reconduzida, por seu turno, a esse conjunto de representações, atitudes e comportamentos perante o mundo da política configurados pela antiga noção - aqui recuperada e parcialmente reconstruída - do familismo amoral.

Mais importante do que o valor intrínseco de qualquer das duas expressões, distância ao poder e familismo amoral, é a identificação de dois grandes nexos históricos de longa duração, que se constituíram como elos mediadores entre aqueles dois fenômenos. Com efeito, entre outros fatores por identificar, vale apontar, para o analfabetismo como forma de controle social e para o despotismo administrativo do Estado português moderno (e possivelmente do Estado brasileiro) como dois nexos estruturantes das relações entre as elites de poder e as classes subordinadas.

Articuladas entre si, essas duas formas de relacionamento comunicacional e político entre elites e massas terão assim gerado uma forma duradoura de dominação autoritária, que nem a liberalização do sistema político, nem a massificação do ensino, terão sido suficientes, no último quarto de século, para erradicar das representações e práticas políticas da maioria da população portuguesa um sentimento profundo e indiferenciado de distância ao poder.

\section{NOTAS}

1 Os direitos humanos e civis são aqui concebidos, sem prejuízo de uma análise mais profunda, como direitos conferidos à pessoa como tal. Assim, quando se estabelece que ninguém será legalmente discriminado em função da cor da pele, do gênero ou de qualquer outro atributo pessoal ou coletivo, trata-se de um direito negativo, no sentido de que não se reconhece à pessoa direitos particulares, mas tão-somente o usufruto de todos os direitos conferidos às outras pessoas.

2 Tal como assinalam os críticos da cidadania contemporânea, os direitos políticos - ao contrário também do que sucede com os direitos civis e sociais - estão habitualmente associados à nacionalidade da pessoa, deles excluindo, portanto, os imigrantes (Turner, 1993). Trata-se, sem dúvida, de uma discriminação contestável em nome da continuidade dos direitos humanos e, por isso mesmo, tende a verificar-se a extensão de alguns direitos políticos, num número crescente de Estados democráticos, aos residentes de nacionalidade estrangeira.

3 Embora não seja essa a intenção dos legisladores, há algo de paradoxal na obrigatoriedade do direito de voto que confere a este último uma dimensão passiva que não é suposto ter; a demonstração é feita ao contrario pelos movimentos de boicote às eleições, freqüentes em Portugal. Para o Brasil, é re- 
levante o fato de muitos brasileiros mencionarem em pesquisas "o voto como uma obrigatoriedade e não como um direito” (J. M. Carvalho, 2002, p. 26).

4 Para uma revisão aprofundada do debate sobre o "déficit democrático no Brasil", ver M. A. R. Carvalho, 2002.

5 Tendo em conta que nem sempre a pergunta foi formulada de forma idêntica, o grau de desidentificação partidária em Portugal (46\%) situava-se, em 1997, em nível semelhante ao da Suécia (44\%), sendo inferior ao de um regime pós-comunista como a Hungria (59\%), mas bastante superior ao de um regime democrático consolidado, embora há muito conturbado, como a Alemanha (29\%).

6 As organizações consideradas relevantes são as seguintes, por ordem daquelas que recolheram maior número de participantes: coletividades de índole recreativa, cultural, ambiental ou de solidariedade social (16\%); sindicatos (11\%); associações profissionais e econômicas (7\%), e partidos políticos (4\%). Finalmente, dos 32\% de inquiridos que declararam pertencer a um tipo qualquer de associação relevante, $18 \%$ desempenham ou desempenharam funções dirigentes nessas associações, o que corresponde a $6 \%$ do eleitorado português.

7 Excluímos a participação eleitoral, bem como o posicionamento topológico perante a escala Esquerda-Direita, visto nenhum desses indicadores apresentar variações significativas entre si nem com a propensão dos cidadãos para a ação coletiva ou para a automobilização em defesa dos seus interesses e valores. Com efeito, não só a participação eleitoral e o posicionamento ideológico não introduziriam estatisticamente diferenças significativas na distribuição dos inquiridos perante o exercício da cidadania, como elas parecem constituir, na realidade, reações relativamente indiferenciadas à oferta prevalecente no mercado político. Excluímos também da medida da cidadania a identificação partidária, a fim de afastar da presente discussão a problemática da adequação da atual oferta à procura latente de bens políticos. Seja como for, a fraca correlação que a identificação partidária possui com o exercício da cidadania tal como optamos por calculá-lo é recuperada através da mediação dos índices de participação e de mobilização.

8 A associação negativa entre o sexo feminino a participação cívica em geral não é exclusiva de sociedades como a portuguesa; com efeito, estudos muito recentes mostraram que o mesmo acontece nos Estados Unidos (Burns, Schlozman e Verba, 2001).

9 A adaptação consistiu em substituir a expressão management, utilizada pelo autor, por governantes, emprestando assim um cunho político ao conceito genérico de poder. O cálculo do índice, formado a partir de três indicadores (ver a seguir), seguiu também o método adotado pelo autor, de modo a permitir a comparação temporal entre as populações inquiridas.

10 Cf. Hofstede, 1968, pp. 65-109, sobretudo Figura 3.1 , p. 77 , mostrando que os empregados portugueses da empresa em questão se encontravam em 1968 na $25^{\text {a }}$. posição da tabela de distância ao poder, com 63 pontos para uma média de 51 nos quarenta países então estudados, enquanto hoje em dia o conjunto da população somava 86 pontos numa escala de distanciamento crescente.

11 Faoro, 1998, por exemplo pp. 164-165 do volume 1, a concluir o capítulo sobre "A obra de centralização colonial": "Nenhuma comunicação, nenhum contacto, nenhuma onda vitalizadora flui entre o governo e as populações: a ordem se traduz na obediência passiva ou no silêncio. Não admira que, duzentos anos depois, as liberdades públicas só existam para divertimento de letrados".

12 Por exemplo, Lucena (1981) em crítica a Wiarda, mas também eu próprio em vários ensaios publicados e inéditos sobre o fascismo português em perspectiva comparada (Cabral, 1982).

13 Sobre as classes sociais em Portugal, cf. entre muitas outras contribuições, Martins (1998); Estanque e Mendes (1997); Cabral (1998; 1999a e b). Especificamente sobre o campesinato nortenho, cf. Silva (1998), que é o único a aludir explicitamente ao trabalho de Banfield. A antropologia social dos espaços rurais portugueses, apesar de haver crescido bastante nos últimas décadas, nunca analisou nem discutiu a noção de familismo amoral, ao contrário do que sucedeu em vários outros "terrenos mediterrânicos".

14 Dois-terços dos inquiridos pensam que "os portugueses têm medo de mostrar que discordam das decisões dos governantes" ( $27 \%$ pensam que isso ocorre "muito freqüentemente" e 40\%, "algumas vezes").

15 R. Bendix refere-se, no seu livro clássico sobre a cidadania, a existência de "voto plural" na Inglaterra em favor dos universitários, privilégio que o autor classifica surpreendentemente como "inócuo", e também na Bélgica até final do século XIX (Bendix, 1996, p. 133).

16 Um estudioso das relações entre alfabetização e poder local assinala que, na década de 1880, a diferenciação feita no sistema eleitoral português entre eleitores e elegíveis, coincidindo estes últimos com os alfabetizados, era praticamente única nos países 
europeus da época (Gameiro, 1997, p. 136); ver também Almeida, 1991.

17 Salvo melhor informação, a primeira tradução completa da Bíblia impressa em português foi obra de um convertido ao protestantismo, João Ferreira de Almeida, e data de finais do século XVII (Novo Testamento, 1681) e meados do século XVIII (Antigo Testamento, 1738-1744); mas na realidade, a primeira Bíblia católica em português deve-se ao Pe. António Pereira de Figueiredo e só foi impressa em finais do séc. XVIII (Novo Testamento, 1778-1781; Antigo Testamento, 1783-1790)!

18 Vale a pena ilustrar esse aspecto do controle sobre a circulação dos livros religiosos com o caso das Bíblias protestantes em castelhano, impressas na Inglaterra a fim de serem exportadas para a Península Ibérica, que foram apreendidas em Lisboa pela Inquisição entre 1606 e 1611 (Marquilhas, 1996, pp. 177-185). No que diz respeito à produção de livros, vale ainda recordar que, para além da censura regularmente exercida sobre editores e livreiros, as autoridades religiosas promoviam, ocasionalmente, o exame das bibliotecas particulares (idem, pp. 184 passim), como sucedeu concretamente no bispado de Lamego em 1621 (idem., pp. 192 passim). Esses pormenores são reveladores do carácter sistemático e metódico de como o controle sobre a produção e a circulação da palavra impressa era feito em Portugal no Antigo Regime.

19 No que diz respeito a esse problema metodológico dos estudos históricos sobre a alfabetização, é lícito perguntar se essas assinaturas em documentos administrativos permitem ter a certeza de que as pessoas sabiam efetivamente ler e, além disso, se realmente liam e o quê? Como crítica à posição habitualmente tomada pelos investigadores nesta área, pode citar-se contra a autora da excelente $\mathrm{Fa}$ culdade das Letras o seu próprio exemplo encontrado nos róis das bibliotecas particulares do bispado de Lamego examinadas pela Inquisição de Coimbra em 1621: "Diguo eu Domingos Fernandes [...] que pedi ao Padre Domingos Hemriques que me assentasse estas cartilhas por eu não saber escrever onde me eu asiney" (Marquilhas, p. 203)

20 Segundo Rita Marquilhas (1996, p. 127), essa fixação só se verificou em 1911 após a implantação da República; a opinião é corroborada por J. P. Magalhães (1994, p. 519), segundo o qual a "ausência de política na normalização ortográfica da Língua [...] uma certa arbitrariedade da escrita e alguma ausência de tradição escrevente favoreceram [...] o reforço da oralidade".
21 Ver, por exemplo, J. P. Magalhães (1994, p. 520) sobre a ausência de dialetos em Portugal: "A ausência de dialectos fortemente arreigados e o seu não reconhecimento [grifo meu] favoreceram a inércia por parte das autoridades, que se traduz no não fomento de uma instrução efetiva e de uma escolarização por parte das populações, sobretudo rurais".

22 Desde as dúzias de panfletos individuais solicitando empregos ou a reparação de danos por perda de emprego após a conquista do poder pelos liberais, em 1834, até as sucessivas camadas de funcionários públicos recrutados pelos governos democráticos após o 25 de abril, passando pela sempiterna controvérsia acerca da isenção dos chamados concursos públicos abundantemente documentada na tese de Tavares de Almeida sobre as elites liberais na segunda metade do século XIX (Almeida, 1995). Para as formas recentes do clientelismo político-partidário, cf. F. Farelo Lopes (1997), na linha de Luis Roniger (em J. Alexander, 1988).

23 Ver, por exemplo, vários dos ensaios publicados na coletânea de P. Birnbaum e J. Leca (1986), maxime F. Chazel, "Individualisme, mobilisation et action collective".

24 Apenas 3\% revelaram, no nosso inquérito de 1997, tê-lo feito alguma vez!

$25 \mathrm{Na}$ Introdução, Cavalcanti de Albuquerque assinala a passagem do "voto de cabresto" ao "voto mercadoria": "A repetição do processo eleitoral [...] vai sujeitar o patriarcalismo político do coronel [...] a progressivas modificações [...]. O voto que o matuto confiava ao coronel como se fosse um bem da natureza, uma planta do mato sem valor, começa a eletrizar-se com o atrito de sucessivas lides políticas [...]. O voto começa a ser favor; de favor se torna objeto de negócios [...]. Se o voto do coronel era antes como o seu gado [...] agora também é mercadoria que lhe é vendida em troca de favores, roupa, sapatos, empregos [...]" (Albuquerque e Vilaça, 1978, pp. 39-40).

\section{BIBLIOGRAFIA}

ALBUQUERQUE, R. C. \& VILAÇA, Marcos V. (1978), Coronel, coronéis, 2. ed. Brasília, Editora da UnB.

ALEXANDER, Jeffrey C. (ed.). (1998), Real civil societies: dilemmas of institutionalization. Londres, Sage. 
ALMEIDA, Pedro Tavares de. (1991), Eleições e caciquismo no Portugal oitocentista, 18681890. Lisboa, Difel.

(1995), A construção do Estado liberal: elite política e burocracia na Regeneração. Tese de doutorado, Lisboa, Faculdade de Ciências Sociais e Humanas da Universidade Nova de Lisboa.

BANFIELD, Edward. (1958), The moral basis of a backward society. Glencoe, The Free Press (aqui utilizarei a edição italiana organizada por Domenico De Masi e comentada por vários outros autores: $L e$ basi morali di una società arretrata, Bologna, Il Mulino, 1976).

BASTOS, José Timóteo da Silva. (1926), História da censura intelectual em Portugal: ensaio sobre a compressão do pensamento português. Coimbra, Imprensa da Universidade.

BEETHAM, David (ed.). (1994), Defining and measuring democracy. Londres, Sage Publications.

BENAVENTE, Ana et al. (1996), A literacia em Portugal: resultados de uma pesquisa extensiva e monográfica. Lisboa, Fundação Calouste Gulbenkian/Instituto de Ciências Sociais.

BENDIX, Reinhard. ([1964] 1996), Construção nacional e cidadania. São Paulo, Edusp.

BURNS, Nancy; LEHMAN SCHLOZMAN, K. \& VERBA, Sidney. (2001), The private roots of public action: gender, equality and political participation. Cambridge, Massachusetts, Harvard University Press.

CABRAL, Manuel Villaverde. (1982), "Portuguese fascism in comparative perspective". Trabalho apresentado no IPSA Congress, Rio de Janeiro.

(1983), "L'évolution du monde rural portugais au $\mathrm{XX}^{\mathrm{e}}$. siècle: L'état de la question", in Pasquale Villani (org.), Trasformazioni delle società rurali nei paesi dell'Europa occidentale e mediterranea, Nápoles, Guida.

(1986), "État et paysannerie: politiques agricoles et stratégies paysannes au Portugal depuis la Seconde Guerre Mondiale". Sociologia Ruralis - Journal of the European Society for Rural Sociology, XXVI (1), Aachen, Van Gorcum.

. (1991), "Pluriactivité et stratégies paysannes d'abandon de l'agriculture: deux exemples", in Maurice Godelier (org.), Transitions et subordinations au capitalisme, Paris, Editions de la Maison des Sciences de l'Homme.

. (1997), Cidadania política e equidade social em Portugal. Oeiras, Celta.

(1998), "Mobilidade social e atitudes de classe em Portugal". Análise Social, XXXIII: 146-147, Lisboa, ICS.

(1999a), "Classes sociais em Portugal, 1930-1970", in A. Barreto e M. F. Mónica (orgs.), Dicionário de história de Portugal - Suplemento, Porto, Livraria Figueirinhas.

(1999b), "Mobilidade social e atitudes de classe em Portugal". Análise Social, 164-147: 381-414.

. (2000a), "O exercício da cidadania política em Portugal", in M.V. Cabral, Jorge Vala e João Freire (orgs.), Trabalho e cidadania: inquérito permanente às atitudes sociais dos portugueses, Lisboa, Imprensa de Ciências Sociais.

. (2001), "Espaços e temporalidades da educação em Portugal", in A. Nóvoa (org.), Espaços de educação, tempos de formação, Lisboa, Fundação Calouste Gulbenkian.

CARVALHO, J. Murilo de. (1987), Os bestializados: o Rio de Janeiro e a República que não foi. São Paulo, Companhia das Letras.

(2001), Cidadania no Brasil: o longo caminho. Rio de Janeiro, Civilização Brasileira. 
. (2002a), "Cidadania, estadania, consumismo: os impasses da democracia", in L. C. Fridman (org.), Politica e cultura: século XXI, Rio de Janeiro, ALERJ/Relume Dumará.

(org.). (2002b), "Introdução", Visconde do Uruguai, Editora 34, S. Paulo.

CARVALHO, M. ${ }^{a}$ Alice Rezende de. (2002), "Cultura política, capital social e a questão do déficit democrático no Brasil", in L. Werneck Vianna (org), A democracia e os três poderes no Brasil. Belo Horizonte/Rio de Janeiro, Editora da UFMG/Iuperj/Faperj.

CAHAYANOV, A. V. (1966), The theory of peasant economy. Homewood, Ill., R. D. Irwin (tradução norte-americana do original russo, 1925).

CHAZEL, François. (1986), "Individualisme, mobilisation et action collective", in Pierre Birnbaum e Jean Leca, Sur l'individualisme, Paris, Presses de la FNSP.

COHEN, Jean \& ARATO, Andrew. (1992), Civil society and political theory. Cambridge, Massachusetts, The MIT Press.

ELSTER, Jon. (1985), "The market and the forum: three varieties of political theory", in $\mathrm{J}$. Elster e A. Hylland, Foundations of social choice, Cambridge, Cambridge University Press.

(1993a), Sour grapes: studies in the subversion of rationality. Cambridge, Cambridge University Press.

(1993b), "Consequences of constitutional choice: reflections on Tocqueville", in J. Elster e R. Slagstad, Constitutionalism and democracy, Cambridge, Cambridge University Press.

ESTANQUE, Elísio \& MENDES, José Manuel. (1997), Classes e desigualdades sociais em Portugal: um estudo comparativo. Porto, Afrontamento.

FAORO, Raymundo. (1998), Os donos do poder: formação do patronato político brasileiro. 13. ed. São Paulo, Editora Globo.
FRANCO, Ma ${ }^{a}$. Sylvia de Carvalho. (1969), Homens livres na ordem escravocrata. São Paulo, Instituto de Estudos Brasileiros.

FREIRE, André. (2001), Mudança eleitoral em Portugal: clivagens, economia e voto nas eleições legislativas, 1983-1999. Oeiras, Edições Celta.

FREIRE André \& MAGALHÃES, Pedro. (2002), A abstenção eleitoral em Portugal. Lisboa, ICS.

GAMEIRO, Fernando Luís. (1997), Entre a escola e a lavoura: o ensino e a educação no Alentejo, 1850-1910. Lisboa, Instituto de Inovação Educacional.

GOODY, Jack. (1986), The logic of writing and the organization of society. Cambridge, Cambridge University Press.

(1987), The interface between the written and the oral. Cambridge, Cambridge University Press.

HOFSTEDE, G. ([1968] 1972), Culture's consequences: international differences in work-related values. Londres, Sage.

HUNTINGTON, S. P. (1991), The third wave: democratization in the late $20^{\text {th }}$ century. Norman, University of Oklahoma Press.

JOHNSTON, M. (1993), "Disengaging from democracy", in R. Jowell et al. (eds.), International social attitudes: the BSA $10^{\text {th }}$ report, Dartmouth, Aldershot.

KLUEGEL, J. R.; MASON, D. S. \& WEGENER, B. (eds.). (1995), Social justice and political change: public opinion in capitalist and post-communist states. Nova York, Walter de Gruyter.

LESSA, Renato. (1999), A invenção republicana: Campos Sales, as bases e a decadência da Primeira República Brasileira. 2. ed. (revista), Rio de Janeiro, TopBooks.

LINZ, J. J. (1988), "Legitimacy of democracy and the socioeconomic system", in M. Dogan (ed.), Comparing pluralist demo- 
cracies: strains on legitimacy, Boulder, Colorado, Westview.

LOPES, Fernando Farelo. (1997), "Partisanship and political clientelism in Portugal". South European Society \& Politics, 3: 2751, Londres, Frank Cass.

LOPES, F. Farelo \& FREIRE, André. (2002), Partidos politicos e sistemas eleitorais. Oeiras, Celta.

LUCENA, Manuel de. (1981), "Uma leitura americana do corporativismo português". Análise Social, XVII (66): 415-434, Lisboa, ICS.

LUHMANN, N. ([1969] 1980), Legitimação pelo procedimento. Brasília, Editora da UnB.

LYTTELTON, Adrian. (2000), "Liberalism and civil society in Italy: from hegemony to mediation", in Nancy Bermeo e Philip Nord (eds.), Civil society before democracy: lessons from the $19^{\text {th }}$ century, Lanham, Maryland, Rowman \& Littlefield Publishers, Inc.

MAGALHÃES, Justino Pereira. (1994), Ler e escrever no mundo rural do Antigo Regime: um contributo para a história da alfabetização e da escolarização em Portugal. Braga, Universidade do Minho.

MARQUILHAS, Rita. (1996), A faculdade das letras: leitura e escrita em Portugal no século XVII. Tese de doutorado, Lisboa, Faculdade de Letras da Universidade de Lisboa.

MARSHALL, Gordon; SWIFT, Adam \& ROBERTS, S. (eds.). (1997), Against the odds? Social class and social justice in industrial societies. Oxford, Clarendon Press.

MARSHALL, T. H. ([1950] 1992), Citizenship and social class. Londres, Pluto Press.

MARTINS, Hermínio. (1998), Classe, status e poder e outros ensaios sobre o Portugal contemporâneo. Lisboa, Instituto de Ciências Sociais.
NOELLE-NEUMANN, E. ([1984] 1995), La espiral del silencio. Opinión pública: nuestra piel social. Barcelona/Buenos Aires, Ediciones Paidós.

PIZZORNO, Alessandro. (1976), "Familismo amorale e marginalità storica ovvero perchè non c'è niente da fare a Montegrano", in E. Banfield (org. Domenico De Masi), Le basi morali di una società arretrata, Bologna, Il Mulino.

POINSARD, Léon. (1910), Le Portugal inconnu. Paris, La Science Sociale.

POPPOVIC, M. \& PINHEIRO, P. S. (1995), "Comment consolider la démocratie? L'option des droits de l'homme". Revue Internationale des Sciences Sociales, 143: 91106, Paris, Unesco.

RAMOS, Rui. (1988), "Culturas da alfabetização e culturas do alfabetismo em Portugal: uma introdução à história da alfabetização no Portugal contemporâneo". Análise Social, 103/104: 1067-1145.

RAWLS, John. (1971), A theory of justice. Londres, Harvard University Press.

REIS, Elisa Pereira. (1998), Processos e escolhas: estudos de sociologia política. Rio de Janeiro, Contra Capa Livraria.

REIS, Jaime. (1993), "O analfabetismo em Portugal no século XIX: uma interpretação", in O atraso económico português, 1850-1930, Lisboa, Imprensa Nacional (Colecção Análise Social).

ROBINSON, Richard. (1979), Contemporary Portugal: a history. Londres, George Allen \& Unwin.

SALES, Manuel F. Campos. (1998), Da propaganda à presidência. Brasília, Senado Federal (edição fac-similar com introdução de Renato Lessa).

SANTOS, Wanderley Guilherme dos. (1998a), Décadas de espanto e uma apologia democrática. Rio de Janeiro, Rocco. 
(1998b), "Poliarquia em 3D". Dados, 41 (2): 201-280, Rio de Janeiro, Iuperj.

SAWARD, M. (1994), "Democratic theory and indices of democratization", in D. Beetham (ed.), Defining and measuring democracy, Londres, Sage Publications.

SCHMITTER, Philippe C. (1977), "The 'régime d'exception' that became the rule: 48 years of authoritarian domination in Portugal", in L. Graham e H. M. Makler (eds.), Contemporary Portugal: the Revolution and its antecedents, Austin, University of Texas Press.

. (1999), "Opinião pública e 'qualidade' da democracia em Portugal (1992)", in P. C. Schmitter, Portugal do autoritarismo à democracia, Lisboa, Imprensa de Ciências Sociais.

SILVA, Francisco Ribeiro da Silva. (1986), "A alfabetização no Antigo Regime: o caso do Porto e da sua região, 1580-1650". Revista da Faculdade de Letras, 2. ${ }^{\mathrm{a}}$ série (3): 101-163, Universidade do Porto.

SILVA, Manuel Carlos. (1998), Resistir e adaptarse: constrangimentos e estratégias camponesas no Noroeste de Portugal. Porto, Edições Afrontamento.

TEPICHT, Jerzy. (1973), Marxisme et agriculture: le paysan polonais. Paris, Editions $\mathrm{Ar}-$ mand Colin.

TOCQUEVILLE, Alexis de. ([1856] 1967), L'Ancien Régime et la révolution: livre II. Paris, Gallimard (edição organizada por J.-P. Mayer).

TURNER, Bryan J. (ed.). (1993), Citizenship and social theory. Londres, Sage Publications.

TURNER, Bryan \& HAMILTON, Peter (eds.). (1994), Citizenship: critical concepts. Londres/Nova York, Routledge.

VIANNA, F. J. Oliveira. (1949), Instituições políticas brasileiras. 3. ed. Rio de Janeiro, Record, 2 vols.
VIANNA, Luíz Werneck (org.). (2002), A democracia e os três poderes no Brasil. Belo Horizonte/Rio de Janeiro, Editora da UFMG/Iuperj/Faperj.

VIANNA, L. Werneck \& BURGOS, Marcelo. (2002), "Revolução processual do direito e democracia progressiva", in L. Werneck Vianna (org), A democracia e os três poderes no Brasil. Belo Horizonte/Rio de Janeiro, Editora da UFMG/Iuperj/Faperj.

WEBER, Eugene. (1976), Peasants into Frenchmen: the modernization of rural France, 1870-1914. Stanford, Califórnia, Stanford University Press.

WIARDA, Howard J. (1977), Corporatism and development: the Portuguese experience. Amherst, The University of Massachusetts Press.

ZARET, David. (1998), "Neither faith nor commerce: printing and the unintended origins of English public opinion”, in Jeffrey C. Alexander (ed.), Real civil societies: dilemmas of institutionalization, Londres, Sage. 


\section{Anexo Estatístico}

Quadro 1

Identificação Partidária, Segundo o Posicionamento Ideológico (\%)

\begin{tabular}{|c|c|c|c|c|c|c|c|c|c|c|c|c|c|}
\hline \multirow{2}{*}{$\begin{array}{l}\text { Identificação } \\
\text { partidária }\end{array}$} & \multicolumn{13}{|c|}{ Posicionamento ideológico } \\
\hline & 1 & 2 & 3 & 4 & 5 & 6 & 7 & 8 & 9 & 10 & ns & $\mathbf{n r}$ & $\begin{array}{l}\text { Total } \\
\text { linha }\end{array}$ \\
\hline CDS/PP (direita) & $\begin{array}{l}3,5 \\
3,0 \\
\end{array}$ & & & $\begin{array}{l}3,5 \\
1,3\end{array}$ & $\begin{array}{r}12,3 \\
1,5 \\
\end{array}$ & $\begin{array}{l}7,0 \\
3,1 \\
\end{array}$ & $\begin{array}{r}12,3 \\
6,2 \\
\end{array}$ & $\begin{array}{r}24,6 \\
16,9 \\
\end{array}$ & $\begin{array}{r}14,0 \\
27,6 \\
\end{array}$ & $\begin{array}{l}15,8 \\
11,8 \\
\end{array}$ & & $\begin{array}{l}7,0 \\
1,6 \\
\end{array}$ & 3,6 \\
\hline PCP (esquerda) & $\begin{array}{r}25,3 \\
30,3 \\
\end{array}$ & $\begin{array}{r}24,1 \\
33,9 \\
\end{array}$ & $\begin{array}{r}29,1 \\
19,8 \\
\end{array}$ & $\begin{array}{r}11,4 \\
5,7 \\
\end{array}$ & $\begin{array}{l}3,8 \\
0,6 \\
\end{array}$ & $\begin{array}{l}1,3 \\
0,8 \\
\end{array}$ & & $\begin{array}{l}2,5 \\
2,4 \\
\end{array}$ & & & & $\begin{array}{l}2,5 \\
0,8 \\
\end{array}$ & 5,0 \\
\hline MRPP (ext,-esq,da) & $\begin{array}{c}50,0 \\
1,5 \\
\end{array}$ & & $\begin{array}{r}50,0 \\
0,9 \\
\end{array}$ & & & & & & & & & & 0,1 \\
\hline $\begin{array}{l}\text { PPD/PSD } \\
\text { (cent,dir,) }\end{array}$ & 0,6 & 0,6 & 0,6 & 3,5 & 16,6 & 16,2 & 19,1 & 14,3 & 3,2 & 14,3 & 1,3 & 9,6 & 19,8 \\
\hline & 3,0 & 3,6 & 1,7 & 7,0 & 11,1 & 38,9 & 53,1 & 54,2 & 34,5 & 59,2 & 10,5 & 11,8 & \\
\hline PS (centro-esq,da) & & & & & & & & & & 1,0 & & & 26,1 \\
\hline & 18,2 & 37,5 & 44,0 & 53,8 & 30,0 & 22,9 & 15,9 & 7,2 & 13,8 & 5,3 & 5,3 & 16,5 & \\
\hline PSR (ext, esquerda) & & & $\begin{array}{r}25,0 \\
0,9 \\
\end{array}$ & $\begin{array}{r}75,0 \\
1,9 \\
\end{array}$ & & & & & & & & & 0,3 \\
\hline UDP ( ext, esq,da) & & & & $\begin{array}{c}50,0 \\
0,6 \\
\end{array}$ & & & & & & $\begin{array}{r}50,0 \\
1,3 \\
\end{array}$ & & & 0,1 \\
\hline Outro & & & $\begin{array}{c}16,7 \\
0,9 \\
\end{array}$ & & $\begin{array}{r}33,3 \\
0,4 \\
\end{array}$ & $\begin{array}{l}16,7 \\
0,8 \\
\end{array}$ & & $\begin{array}{l}16,7 \\
1,2 \\
\end{array}$ & & & & $\begin{array}{l}16,7 \\
2,6 \\
\end{array}$ & 0,4 \\
\hline Nenhum & & & 5,2 & 6,6 & 37,0 & 6,2 & 3,9 & 2,1 & 1,0 & 2,4 & 4,4 & 4,4 & 44,7 \\
\hline & 43,9 & 25,0 & 31,9 & 29,7 & 56,3 & 33,6 & 24,8 & 18,1 & 24,1 & 22,4 & 81,6 & 81,6 & \\
\hline Total coluna & 4,2 & 3,5 & 7,3 & 9,9 & 29,4 & 8,2 & 7,1 & 5,2 & 1,8 & 4,8 & 2,4 & 16,0 & \\
\hline
\end{tabular}


Quadro 2

Formas Moderadas e Radicais de Mobilização

Análise Fatorial em Componentes Principais

\begin{tabular}{|l|c|c|}
\hline & Factor 1 & Factor 2 \\
\hline Mandar uma carta & $\mathbf{, 8 2}$ &, 18 \\
Contactar um político & $\mathbf{7 9}$ &, 11 \\
Assinar uma petição & $\mathbf{, 7 2}$ &, 36 \\
Organizar uma reunião & $\mathbf{7 1}$ &, 31 \\
\hline Bloquear uma estrada &, 01 & $\mathbf{, 8 0}$ \\
Manifestar na rua &, 31 & $\mathbf{, 7 8}$ \\
Fazer greve &, 34 & $\mathbf{, 6 6}$ \\
Colar cartazes &, 37 & $\mathbf{, 6 4}$ \\
\hline Variância explicada & 49,3 & 13,4 \\
\hline Alpha de Cronbach &, 81 &, 76 \\
\hline $\mathrm{N}$ & 1.617 & 1.615 \\
\hline
\end{tabular}

Quadro 3

Índice de Cidadania Política

Análise Fatorial em Componentes Principais

\begin{tabular}{|l|c|c|c|}
\hline & Factor 1 & Factor 2 & Factor 3 \\
\hline Instrução & $\mathbf{, 7 6}$ &, 24 &, 03 \\
Classe social & $\mathbf{, 7 3}$ &, 02 &, 01 \\
Rendimento & $\mathbf{- , 5 7}$ &, 13 &, 00 \\
Habitat $^{*}$ & $\mathbf{5 2}$ &,- 03, & 12 \\
\hline Gênero &,- 29 & $\mathbf{, 6 7}$ &,- 08 \\
Cidadania &, 34 & $\mathbf{, 6 2}$ &, 10 \\
Mobilização cognitiva &, 22 & $\mathbf{, 5 5}$ &, 14 \\
Exposição aos media informativos &, 39 & $\mathbf{4 8}$ &, 21 \\
\hline Identificação partidária &, 14 &, 33 & $\mathbf{, 6 6}$ \\
Avaliação do sistema político &, 06 &,- 36 & $\mathbf{6 4}$ \\
Posicionamento ideológico &, 15 &, 34 & $\mathbf{5 2}$ \\
\hline Variância explicada & 24,2 & 13,1 & 9,6 \\
\hline
\end{tabular}




\section{Quadro 4}

Índice de Cidadania em Função da Classe Social, da Mobilização Cognitiva, da Instrução, do Gênero, da Exposição aos Media e do Posicionamento Ideológico Análise de regressão linear múltipla

\begin{tabular}{|l|c|c|}
\hline & Beta & $\mathrm{p}<$ \\
\hline Classe social* &, 21 &, 000 \\
Mobilização cognitiva &, 17 &, 000 \\
Instrução &, 15 &, 000 \\
Gênero &, 15 &, 000 \\
Exposição aos media &, 14 &, 000 \\
Posicionamento ideológico &, 06 &, 049 \\
\hline $\mathrm{R}^{2}$ ajustado &, 27 & \\
\hline
\end{tabular}

* Variável dummy

\section{Quadro 5}

Índice de Avaliação do Sistema Político Análise Fatorial em Componentes Principais

\begin{tabular}{|l|c|c|c|}
\hline & Factor 1 & Factor 2 & Factor 3 \\
\hline Compreensão da política & $\mathbf{, 7 5}$ &,- 05 &,- 08 \\
Mobilização política & $\mathbf{, 7 0}$ & $-0,4$ &, 06 \\
Percepção de influência política & $\mathbf{, 5 9}$ &, 10 &, 04 \\
Participação associada & $\mathbf{, 5 6}$ &, 02 &,- 01 \\
\hline Avaliação dos governantes &, 01 & $\mathbf{, 8 5}$ &,- 01 \\
Avaliação dos partidos &, 02 & $\mathbf{8 3}$ &,- 09 \\
Avaliação dos funcionários &,- 01 &, 00 & $\mathbf{, 8 1}$ \\
Avaliação dos tribunais &, 03 &,- 09 & $\mathbf{7 8}$ \\
\hline Variância explicada & 21,5 & 19,5 & 14,9 \\
\hline Alpha de Cronbach &, 60 &, 59 &, 44 \\
\hline N & 1.574 & 1.473 & 1.463 \\
\hline
\end{tabular}




\section{Caracterização da População Inquirida}

\begin{tabular}{|c|c|c|c|c|}
\hline \multicolumn{6}{|c|}{ Índice de mobilização cognitiva (\%) } \\
$\begin{array}{c}\mathbf{1} \\
\text { Forte }\end{array}$ & $\begin{array}{c}\mathbf{2} \\
\text { Média }\end{array}$ & $\begin{array}{c}\mathbf{3} \\
\text { Fraca }\end{array}$ & $\begin{array}{c}\mathbf{4} \\
\text { Muito fraca }\end{array}$ & Média \\
\hline 2,6 & 7,9 & 54,6 & 34,9 & 3,2 \\
\hline
\end{tabular}

Índice de exposição à mídia informativa $(\%)$

\begin{tabular}{|c|c|c|c|c|}
\hline $\begin{array}{c}\mathbf{1} \\
\text { Forte }\end{array}$ & $\begin{array}{c}\mathbf{3} \\
\text { Média }\end{array}$ & $\begin{array}{c}\mathbf{4} \\
\text { Fraca }\end{array}$ & Muito fraca & Média \\
\hline 16,1 & 20,6 & 31,8 & 31,5 & $\mathbf{2 , 8}$ \\
\hline
\end{tabular}

Rendimento mensal médio do agregado familiar

\begin{tabular}{|l|c|}
\hline Níveis de rendimento & Distribuição (\%) \\
\hline Baixo (0-300 uros) & 23,2 \\
\hline Médio (301-800 uros) & 46,1 \\
\hline Alto (801-1,500 uros) & 19,7 \\
\hline Muito alto (>1,500 uros) & 8,4 \\
\hline
\end{tabular}

Classe social subjectiva

\begin{tabular}{|l|c|}
\hline Designação & Distribuição (\%) \\
\hline Baixa & 15,9 \\
\hline Trabalhadora & 39,4 \\
\hline Média baixa & 13,6 \\
\hline Média & 25,9 \\
\hline Alta/Média alta & 2,9 \\
\hline Ns/Nr & 3,4 \\
\hline
\end{tabular}

Nível de escolaridade

\begin{tabular}{|l|c|}
\hline Níveis de escolaridade & Distribuição (\%) \\
\hline Nenhum & 13,4 \\
\hline Primário & 44,9 \\
\hline
\end{tabular}




\begin{tabular}{|l|c|}
\hline Preparatório + Secundário incompleto & 24,6 \\
\hline Secundário completo & 8,4 \\
\hline & \\
Superior & 8,8 \\
\hline
\end{tabular}

\begin{tabular}{|l|c|}
\hline \multicolumn{2}{|c|}{ Classe social* } \\
\hline Designação & Distribuição (\%) \\
\hline Grande/Média burguesia & 9,9 \\
\hline Nova burguesia assalariada & 11,2 \\
\hline Salariato terciário & 27,2 \\
\hline Pequena burguesia tradicional & 8,6 \\
\hline Trabalhadores manuais independentes & 11,2 \\
\hline Salariato manual & 31,8 \\
\hline
\end{tabular}

* Só foi possível definir a classe social dos inquiridos com profissão.

Habitat

\begin{tabular}{|l|c|}
\hline Designação & Distribuição (\%) \\
\hline Urbano & 49 \\
\hline Suburbano & 32 \\
\hline Rural & 19 \\
\hline
\end{tabular}




\section{O EXERCÍCIO DA CIDADANIA POLÍTICA EM PERSPECTIVA HISTÓRICA (PORTUGAL E BRASIL)}

\section{Manuel Villaverde Cabral}

Palavras-chave

Cidadania; Estado; Sociedade civil; Familismo amoral.

A exposição deste artigo divide-se em duas partes bem distintas. $\mathrm{Na}$ primeira, após discussão das noções de cidadania e qualidade da democracia, são apresentados os resultados de um survey sobre o exercício da cidadania política em Portugal. Todas as medidas convencionais indicam um débil exercício dos direitos políticos pela população desse país. Os correlatos sociológicos do exercício da cidadania são relativamente previsíveis, confirmando a tendência para a concentração dos instrumentos da participação e da representação política pelas camadas com instrução e capital social mais elevados. Em contrapartida, o forte distanciamento sentido em relação ao poder político atravessa a população de forma indiferenciada. A segunda parte é uma pesquisa histórica de fatores que ajudam a explicar, a partir da constituição real da sociedade civil, a atual distância ao poder. No decurso da pesquisa, são discutidos vários autores que se detiveram sobre a questão da cidadania no Brasil. Dois elementos são identificados na cadeia de efeitos que gerou os déficits de cidadania atualmente verificados: a falta de instrução das massas e o despotismo administrativo do Estado. Como conclusão, a explicação da distância ao poder entra também em conta com estratégias populares, cuja negatividade à luz do conceito liberal de cidadania pode esconder dimensões positivas de resistência e adaptação, como sucede com configurações sociais como o chamado "familismo amoral".

\section{THE EXERCISE OF POLITICAI CITIZENSHIP FROM A HISTO- RICAL PERSPECTIVE (PORTU- GAL AND BRAZIL)}

\section{Manuel Villaverde Cabral}

\section{Keywords}

Citizenship; State; Civil-society; Amoral-familism.

The paper is divided in two clearly distinct parts. In the first one, after discussing the notions of citizenship and quality of democracy, the results of a survey showing a weak propensity of the Portuguese population to exercise its citizenship rights are presented. The sociological correlates are predictable and they tend to confirm the tendency of strata with more education and social capital to concentrate in their hands the instruments of political participation and representation. On the contrary, the distance felt by the majority of the population towards political power does not depend on its social properties. In the second part, the results of a historical research accounting for such "power distance' from the standpoint of 'real civil societies' are presented. In the course of the presentation, the research will be expanded to Brazil with the help of several authors who have discussed the issue of citizenship there. Two main elements are identified in the chain of effects accounting for deficits in the exercise of rights: mass illiteracy and the 'administrative despotism' of the State To conclude, popular strategies of resistance and adaptation to modernization, however negative in the light of the liberal notion of citizenship, such as the so-called 'amoral familism', are called upon in order to more fully account for the distance towards political power felt in Portugal and perhaps Brazil.

\section{L'EXERCICE DE LA CITOYEN- NETÉ POLITIQUE D'APRÈS UNE PERSPECTIVE HISTORI- QUE (PORTUGAL ET BRÉSIL)}

\author{
Manuel Villaverde Cabral
}

Mots-clés

Citoyeneté; État; Société civile; Familisme amoral.

Cet article est divisé en deux parties distinctes. Dans une première partie, après la discussion de notions de citoyenneté et de qualité de la démocratie, nous présentons les résultats d'une enquête qui indique un exercice débile de la citoyenneté politique au Portugal. Les corrélats sociologiques de l'exercice de la citoyenneté sont prévisibles et confirment la tendance des couches sociales possédant une instruction et un capital social plus élevés pour la concentrer dans les mains des instruments de participation et de représentation politiques. En contrepartie, l'importante distance perçue par rapport au pouvoir politique traverse la population de forme indifférenciée. La seconde partie est une recherche historique de facteurs qui aident à expliquer, à partir de la constitution réelle de la société civile, celle de la "distance du pouvoir". Tout au long de notre article, la recherche sera élargie au Brésil grâce à l'aide de plusieurs auteurs qui se sont penchés sur la question de la citoyenneté dans ce pays. Deux éléments sont identifiés dans la chaîne d'effets qui aura géré les déficits de citoyenneté que l'on vérifie actuellement: l'illettrisme des masses et le despotisme administratif de l'État. En conclusion, l'explication de la distance par rapport au pouvoir entre également en compte avec des stratégies populaires, dont la négation à la lumière du concept libéral de citoyenneté peut cacher des dimensions positives de résistance et d'adaptation, comme il se passe avec le "familisme amoral ".. 